\title{
ИСТОЧНИКОВЕДЕНИЕ
}

\section{Новые поступления в Научный архив Калмыцкого научного центра РАН: коллекция семьи Зольвановых как источник по истории калмыцкого буддизма}

\section{Эльза Петровна Бакаева ${ }^{1}$}

${ }^{1}$ Калмыцкий научный центр РАН (д. 8, ул. им. И. К. Илишкина, 358000 Элиста, Российская Федерация)

доктор исторических наук, заместитель директора, ведущий научный сотрудник

(iD) 0000-0002-5188-1202. E-mail: bakaevaep@kigiran.com

(c) КалмНЦ РАН, 2021

(C) Бакаева Э. П., 2021

Аннотация. Введение. В 2019 г. в Научный архив Калмыцкого научного центра РАН благодаря доценту Университета Тулузы им. Жана Жореса (г. Тулуза, Франция) Дани Савелли и госпоже Жаклин Шасселю поступила коллекция, представляющая собой архив семьи калмыков-эмигрантов во Франции, - уникальные документы, свидетельствующие о жизни калмыцкой диаспоры. Цель статьи - дать общую характеристику коллекции, а также оценку ее как источника по истории калмыцкого буддизма. $P e$ зультаты. Коллекция семьи Зольвановых из Научного архива КалмНЦ РАН включает 66 предметов. Среди них фотографии и копии с них, письма официальные и личного характера, буддийские тексты и изображения буддийских божеств (оттиски и фотографии, открытки). Несмотря на относительно небольшое количество предметов данной коллекции, она имеет важное значение для исследования как истории российской эмиграции на примере одной из калмыцких семей, так и истории буддизма среди российских народов. В статье публикуется часть редких фотоснимков, свидетельствующих о связях между калмыками-эмигрантами, расселившимися в разных концах света, а также об их связях с тибетскими монастырями.

Ключевые слова: научный архив, источник, семейная коллекция, буддизм, калмыки, геше Вангъял

Благодарность. Исследование проведено в рамках государственной субсидии - проект «Комплексное исследование процессов общественно-политического и культурного развития народов Юга России» (номер госрегистрации: АААА-А19-119011490038-5). Выражаю благодарность доценту Университета Тулузы им. Жана Жореса Дани Савелли, а также Жаклин Шасселю за сохранение коллекции для научного архива и содействие в передаче коллекции документов в КалмНЦ РАН.

Для цитирования: Бакаева Э. П. Новые поступления в Научный архив Калмыцкого научного центра РАН: коллекция семьи Зольвановых как источник по истории калмыцкого буддизма // Монголоведение. 2021. Т. 13. № 3. С. 504-535. DOI: 10.22162/25001523-2021-3-504-535 


\title{
New Arrivals to Scientific Archives of Kalmyk Scientific Center (RAS): The Zolvanoff Family Collection as a Historical Source of Kalmyk Buddhism
}

\author{
Elza P. Bakaeva ${ }^{1}$ \\ ${ }^{1}$ Kalmyk Scientific Center of the RAS (8, Ilishkin St., 358000 Elista, Russian Federation) \\ Dr. Sc. (History), Deputy Director, Leading Research Associate \\ iD 0000-0002-5188-1202. E-mail: bakaevaep@kigiran.com
}

\author{
(C) KalmSC RAS, 2021 \\ (C) Bakaeva E. P., 2021
}

\begin{abstract}
Introduction. In 2019, thanks to Dani Savelli, Associate Professor of the University of Toulouse Jean Jaures (Toulouse, France) and Ms. Jacqueline Chasselut, the collection of archival materials of a Kalmyk emigrant family in France was received by the Archive of the Kalmyk Scientific Center. The collection contains unique documents testifying to the life of the Kalmyk diaspora abroad. The purpose of the article is to give a general overview of the collection, as well as to examine it as a source on the history of Kalmyk Buddhism. Results. The Zol'vanovs' collection, now a part of the records of the Archive of the Kalmyk Scientific Center includes 66 items, such as photographs and copies of photographs, official and personal letters, postcards, Buddhist texts, and images of Buddhist deities (prints, photographs, and postcards). Thus, despite the relatively small size of the collection, it is an important source as an example of a Kalmyk family abroad both in terms of history of Russian emigration and of Buddhism of the Russian peoples. The article publishes some rare photographs illustrative of the ties between the Kalmyk emigrants settled in different parts of the world, as well as of their interaction with Tibetan monasteries.
\end{abstract}

Keywords: scientific archive, source, family collection, Buddhism, Kalmyks, Geshe Wangyal

Acknowledgements. The reported study was funded by government subsidy — project name 'Sociopolitical and Cultural Development of South Russia's Peoples: Comprehensive Studies of Respective Processes' (state reg. no. AAAA-A19-119011490038-5). I extend heartiest gratitude to Ms. Dany Savelli, Assistant Professor at Toulouse University, and Ms. Jaqueline Chasselut for having preserved the collection and facilitated its delivery to Kalmyk Scientific Center of the RAS.

For citation: Bakaeva E. P. New Arrivals to Scientific Archives of Kalmyk Scientific Center (RAS): The Zolvanoff Family Collection as a Historical Source of Kalmyk Buddhism. Mongolian Studies (Elista). 2021; 13 (3): 504-535. (In Russ.). DOI: 10.22162/2500-15232021-3-504-535

\section{Введение}

Научный архив Калмыцкого научного центра РАН - ведомственный архив академического учреждения. Его комплектование началось с 1957 г., когда в первый год после восстановления автономии Калмыкии был вновь открыт Калмыцкий научно-исследовательский институт языка, литературы и истории, учрежденный указом Совета народных комиссаров Калмыцкой АССР от 31 мая 1941 г. Научный архив Калмыцкого научного центра РАН ныне насчитывает около 50 тысяч единиц хранения. Его фонды постоянно пополняются документами о текущей деятельности учреждения, а также фондами ученых и 
общественных деятелей; проводится кропотливая работа по описанию и каталогизации фондов архива. В последние годы научный архив стал пополняться также ценными электронными копиями письменных памятников, которые поступили в Научный архив КалмНЦ РАН из других архивохранилищ, а также видеоматериалами, поступающими из Центрального калмыцкого хурула благодаря сотрудничеству с буддийской сангхой республики. Новые поступления в научный архив, таким образом, фиксируются постоянно.

В 2019 г. в научный архив поступила примечательная коллекция семьи французских калмыков Зольвановых. Цель статьи - дать общую характеристику коллекции, а также оценку ее как источника по истории калмыцкого буддизма.

\section{Происхождение коллекции: о семье Зольвановых}

Судьба семейных архивов не всегда бывает простой. Так случилось и с архивом семьи Зольвановых. Коллекция была передана в архив Калмыцкого научного центра РАН госпожой Жаклин Шасселю благодаря содействию известного специалиста в области исследований русской культуры и литературы, а также религиозных направлений, связанных с буддизмом, члена бюро исследовательского общества «Российская империя, СССР и постсоветский мир» и российско-немецкого исследовательского общества «Новая религиозная культура в поздней советской и постсоветской России», доцента Университета Тулузы им. Жана Жореса Дани Савелли ${ }^{1}$. Как пояснила Д. Савелли, архив этой семьи был передан у Ж. Шасселю ее родственниками, обнаружившими его в доме, который освобождали от вещей прежних хозяев, и знавшими о ее интересе к тибетской культуре. Ж. Шасселю понимала ценность коллекции для изучения истории буддизма, поэтому, когда она посетила лекцию Д. Савелли в одном из наиболее известных высших учебных заведений Парижа — во Французском колледже (Collège de France), то обратилась с просьбой о содействии в возможной передаче коллекции в музей или научный архив, связанный с буддизмом. Дани Савелли, с которой нас связывает многолетнее сотрудничество, обратилась ко мне с предложением о передаче в Научный архив КалмНЦ РАН семейной коллекции французских калмыков, однако процесс передачи коллекции в ожидании организации специальной поездки затянулся, и когда ведущий научный сотрудник Калмыцкого научного центра РАН А. С. Ряжев был приглашен оргкомитетом одной из конференций для участия в ней, планировавшейся в мае 2019 г. в Париже, мы обратились к нему с просьбой привезти в Элисту документы, которые в ожидании оказии по-прежнему находились у госпожи Ж. Шасселю. Так благодаря посредничеству доцента Тулузского университета Д. Савелли представитель французской стороны мадам Ж. Шасселю передала материалы для Научного архива КалмНЦ $\mathrm{PAH}^{2}$.

${ }^{1}$ Ж. Шасселю предоставила общие сведения о семье Зольвановых, на основании чего был сделан вывод о том, что именно они передали коллекцию в Калмыкию. В связи с этим в публикации, которая вышла вскоре после передачи коллекции Зольвановых в КалмНЦ РАН и в которую были включены редкие фотографии из этой коллекции, указывалось, что она передана через Ж. Шасселю представителями этой семьи французских калмыков [Бакаева 2019: 123].

2 Выражаем благодарность кандидату исторических наук А. С. Ряжеву за содействие в передаче коллекции в Научный архив КалмНЦ РАН. 


\section{Источниковедение}

Несколько слов о семье Зольвановых. Неизвестно, по какой причине документы оказались оставленными в доме, где они могли быть утрачены безвозвратно, но все же коллекция документов была сохранена и затем передана в Калмыкию благодаря вниманию со стороны Ж. Шасселю, которая с трудом, как она отметила, собрала некоторые сведения об этой семье французских калмыков.

Семья Зольвановых проживала в области Бургундия; представителями старшего поколения, которые оказались в эмиграции в период Гражданской войны, были Натали Зембинова (1899-??) и Ермак Зольванов (1889-1990). По сведениям Ж. Шасселю, дочь Н. Зембиновой и Е. Зольванова Кишегте Зольванова была замужем за Паскалем Оганесяном, их потомки проживают в Париже. Вторая дочь Нади Зольванова создала семью с калмыком Николя Чанчиновым и проживала в Париже. У Натали Зембиновой-Зольвановой были также дочери Мари Зольванова и Маргарита Зольванова, сын которой Жан-Шарль ныне проживает в пригороде Парижа - Масси. Потомки, таким образом, носят разные фамилии, живут в разных городах. В их семейной истории большую роль имели связи с буддийскими священнослужителями, что отражено в коллекции, переданной на хранение в Калмыкию.

\section{Общие сведения о коллекции семьи Зольвановых}

Коллекция содержит ценные материалы, и некоторые фотографии из нее сразу же были включены автором статьи в публикацию [Бакаева 2019] с выражением глубокой признательности руководства Калмыцкого научного центра РАН всем членам семьи Зольвановых, а также доценту Университета Тулузы им. Жана Жореса (г. Тулуза, Франция) Дани Савелли и госпоже Жаклин Шасселю, благодаря которым уникальные документы, свидетельствующие о жизни калмыцкой диаспоры во Франции, были переданы в научный архив учреждения.

Состав коллекции неоднороден. Коллекция семьи Зольвановых из Научного архива КалмНЦ РАН включает 66 предметов. Несмотря на относительно небольшое количество предметов данной коллекции, она имеет важное значение для исследования как истории российской эмиграции на примере одной из калмыцких семей, так и истории буддизма среди российских народов.

В нее входят фото и документы, связанные с семьей Зольвановых и калмыками в эмиграции; фото буддийского храма в Белграде, официальные фотографии Далай-ламы XIV Тензин Гьяцо, а также фотографии буддийских калмыцких священнослужителей разных периодов; фото с изображениями храмов и буддийских танка; оттиски и фотографии, открытки с изображениями буддийских божеств; тексты молитв, переписка с известным буддийским учителем, основателем первого буддийского монастыря в США геше Нгаванг Вангъялом и корреспонденция, полученная из тибетских монастырей Индии. Предметы коллекции характеризуют разные периоды из жизни калмыцкой семьи в эмиграции.

Фотографии и документы, связанные с семьей Зольвановых, являются свидетельством поддержания связей между группами калмыцкой диаспоры в эмиграции и сохранения культуры, а также буддийского вероисповедания и буддийской культуры. Так, фотографии представляют не только семью Зо- 
львановых (небольшая фотография родителей в молодом возрасте, оформленная в специальный металлический футляр; семейная фотография отца, матери и дочери (фото 1); отдельный снимок уже пожилого мужчины (Ермака Зольванова?)), но и встречу Натали Зембиновой-Зольвановой и ее дочери с геше Нгаванг Вангъялом.

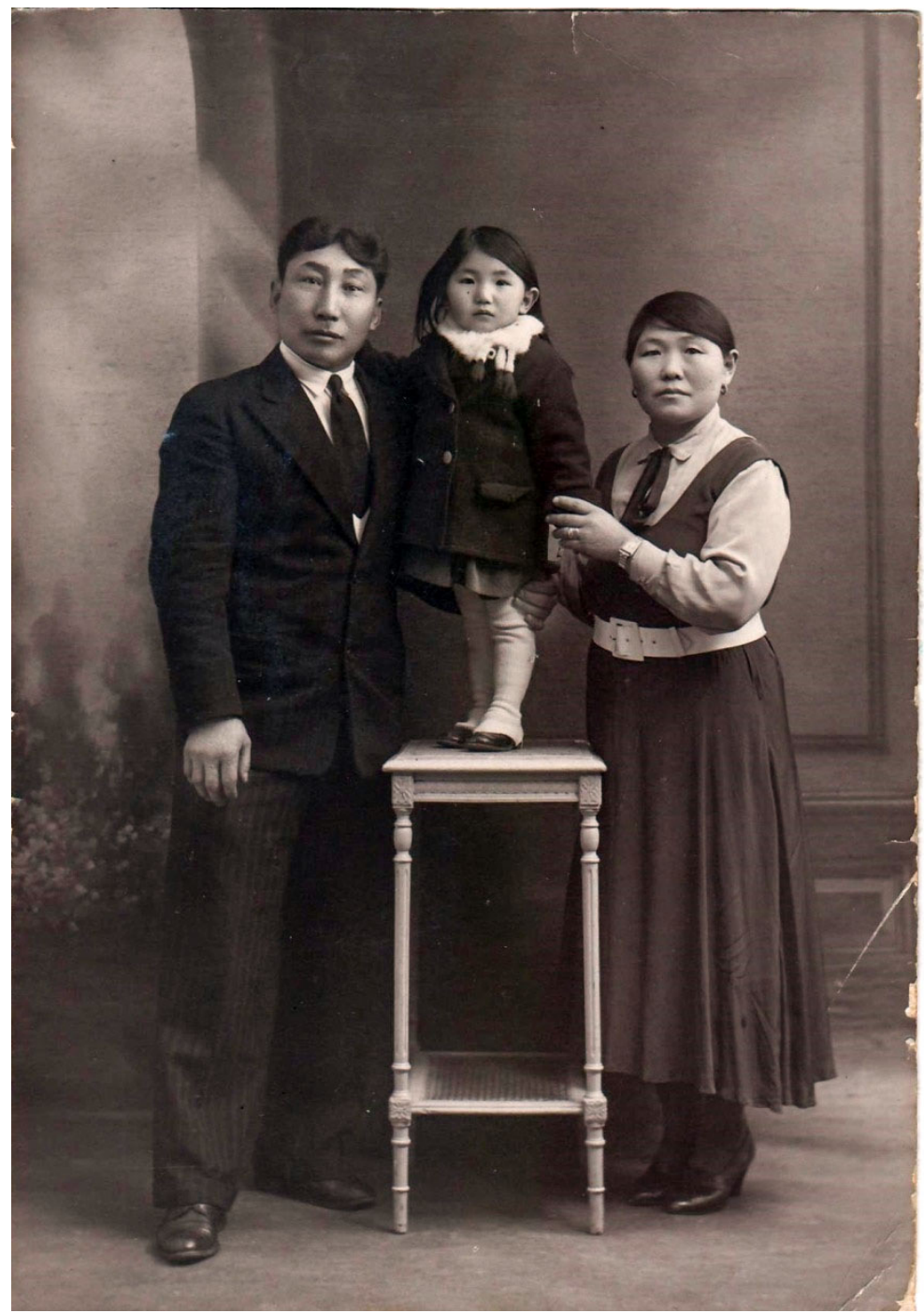

Фото 1. Семья Зольвановых. Около 1934 г. ${ }^{3}$ Из коллекции семьи Зольвановых [Photo 1. The Zolvanoffs, ca. 1943. From the Zolvanoff family archive]

\footnotetext{
Фотография на память. Встреча геше Вангъяла и французских калмыков

Снимок, на котором запечатлен геше Нгаванг Вангъял вместе с Натали Зембиновой-Зольвановой и ее дочерью (фото 2), особенно ценился в семье

${ }^{3}$ Датировка фотографии проведена исходя из возраста дочери, около трех лет, и предположения, что это старшая дочь Н. Зембиновой и Е. Зольванова.
} 


\section{Источниковедение}

французских калмыков: он хранился в специальной рамке с отделанной бархатом оборотной стороной - как память о встрече с буддийским учителем, состоявшейся во Франции. Всего в коллекции имели рамки две фотографии: указанный снимок с геше Вангъялом и фотография Натали и Ермака Зольвановых в молодости. Специально оформлена также фотография Зольвановых с маленькой дочерью (фото 1), однако она не имеет рамки. Изложенное подтверждает особую значимость в коллекции фотографии с геше Вангъялом, в связи с чем рассмотрим некоторые вопросы, связанные со значением этого экспоната коллекции как источника.

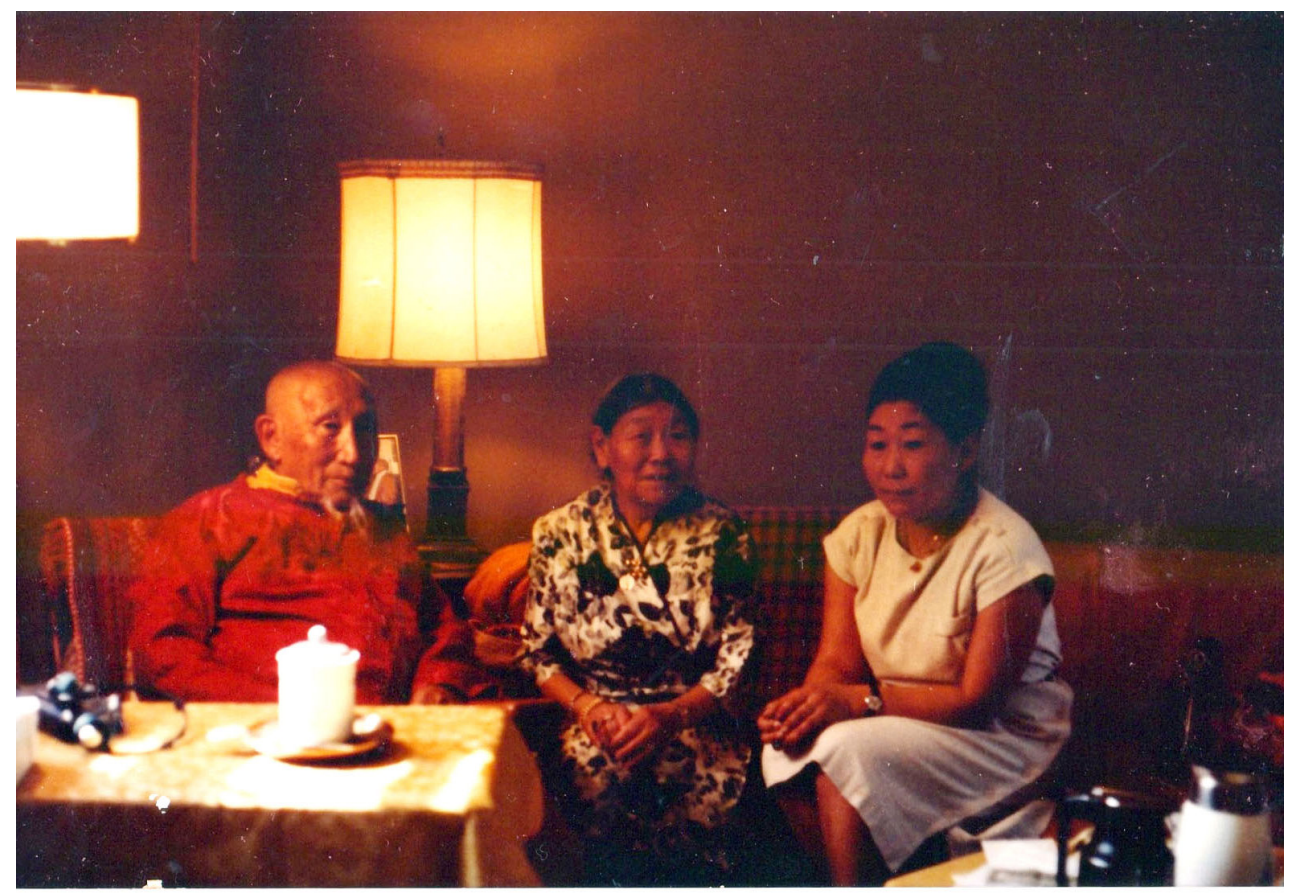

Фото 2. Встреча геше Нгаванг Вангъяла с Н. Зембиновой-Зольвановой и ее дочерью. Из коллекции семьи Зольвановых

[Photo 2. Ven. Geshe Wangyal meets N. Zembinova-Zolvanoff and her daughter. From the Zolvanoff family archive]

Семья Зольвановых состояла в переписке с калмыцким геше. На настоящий момент мы можем лишь предполагать, каким образом между ними были налажены контакты. Однако в любом случае личная встреча являлась особенно важным событием. Даже если эти представители калмыцкого народа и были знакомы в молодости, когда они проживали в Калмыкии, то с того времени прошло несколько десятилетий: выходец из родов багшин-шевнр (көвүдә арван) Боота Лиджиев (известно и другое его имя Лиджин Кеераб, будущий геше Вангъял) отправился на учебу в Тибет в 1922 г., представители семьи французских калмыков попали в эмиграцию ранее. Но упоминание геше Вангъяла о Натали Зембиновой-Зольвановой в переписке как «мадам Зольванов» свидетельствует о том, что они не были родственниками: скорее всего, они близко познакомились именно благодаря связям буддийского учителя и мирян-верующих. 
В 1955 г. геше Вангъял перебрался в США, где в г. Филадельфии и г. Хауэлле (Нью-Джерси) в 1951 г. обосновались калмыки, мигрировавшие из Европы [Бакаева 2019: 118] ${ }^{4}$, и выбор страны эмиграции монаха был связан именно с калмыцкой общиной, с представителями которой был связан священнослужитель с самого прибытия и через которых он, по-видимому, и связался с семьей Зольвановых. В калмыцкой общине были 20 монахов, которые подчинялись указаниям монгольского Дилова-хутухты [Rubel 1967: 110], также волею судьбы оказавшегося в США ${ }^{5}$. Газета «New York Times» ${ }^{6}$ сообщала, что 23 ноября 1952 г. небольшая община мигрантов-калмыков освятила свой первый хурул Раши Гемпил Линг - «,молитвенный дом“ в Америке, в местечке Фривуд Эйкрз, в Нью Джерси» [Хопкинс 2009: 25].

Ко времени прибытия в США геше Вангъяла калмыками были открыты храмы: Раши Гемпил Линг (открыт 3 ноября 1952 г. в приспособленном ${ }^{7}$ помещении [Хопкинс 2009: 25] и вновь открыт в 1958 г. в новом здании) и Таши Лумпо (храм освящен в 1955 г.); позже были открыты буддийские храмы Чойпэл Линг (1977 г.) и Калмыцкий буддийский храм Цзонхавы [Бакаева 2019: 126]. Открытие буддийских храмов было связано с субэтническим составом калмыков и разными социальными группами в их общине, и геше

${ }^{4}$ Геше Нгаванг Вангъял прибыл в США 1955 г. Об этом его ученик Джошуа Катлер пишет во введении к публикации книги своего учителя: «геше приехал в Соединенные Штаты в 1955 году служить священником в калмыцко-монгольской общине, которая переселилась в Нью-Джерси после второй мировой войны» [Геше Вангьял 1993: 12]. До этого времени он в течение четырех лет проживал в Индии (в Калимпонге) на границе с Тибетом, куда перебрался в 1950 г., когда китайские войска, вошедшие в Восточный Тибет, начали двигаться в сторону Лхасы [Геше Вангъял 1993: 21]. В некоторых источниках время, когда геше Вангъял перебрался из Тибета в Индию, указывается более позднее, и речь идет о 1959 г., когда большая часть тибетцев бежала на территорию Индии. Так, даже в одном из материалов, подготовленных пресс-службой Центрального калмыцкого хурула, отмечалось, что геше Вангъял перебрался в Индию вместе с другими монахами в 1959 г., откуда позже переехал в США [В Центральном хуруле 2018]. Однако известно время прибытия геше Вангъяла в США, освещавшегося в газете «The New York Times», об этом в фильме «Калмыцкий геше Нгаванг Вангъял» опубликованы кадры, снятые студией «Movietone News», с интервью самого геше. Но в источниках все же встречается неточность в дате прибытия. Так, в фильме «Калмыцкий геше Нгаванг Вангъял» на основании публикации в «The New York Times» говорится, что геше прибыл в США 3 февраля 1955 г., об этом же пишет ученик геше - Давид Урубджуров [Urubshurow 2013]. А Джошуа Катлер пишет, что геше прибыл в Нью Йорк 5 февраля 1955 г. [Геше Вангъял 1993: 22].

5 Дилова-хутухта приехал в США в начале 1949 г. [Дилова-хутухта 2018: 34; Urubshurow 2013]. Как отмечает Тэло Тулку Ринпоче, «позже он поселился в ФривудЭйкрс в штате Нью-Джерси, где проживало большинство калмыцких эмигрантов, построивших там небольшой буддийский храм» [Дилова-хутухта 2018: 3].

${ }^{6}$ Д. Хопкинс указывает выходные данные этой статьи: «NY Times. 11/24/52. P. 5» [Хопкинс 2009: 25].

${ }^{7}$ Первый калмыцкий храм в США был открыт в гараже, приспособленном для нужд общины [Дилова-хутухта 2018: 37]. 


\section{Источниковедение}

Вангъял основал в 1958 г. еще один храм ${ }^{8}$ - буддийский монастырь, в котором планировал не только совершать буддийские обряды, но и проводить научные исследования. Деятельность геше Вангъяла способствовала развитию буддийской традиции в США. Геше Вангъял основал и официально зарегистрировал в 1958 г. Ламаистский буддийский монастырь Америки (ЛБМА) ${ }^{9}$, который получил название Лабсум Шедруб Линг, с целью развивать научные исследования тибетского буддизма и открыть храм для проведения обрядов, и калмыцкие строители возвели храм, который стал и зданием школы. ЛБМА был позже переименован в Тибетский буддийский исследовательский центр (ТБИЦ), на сайте которого написано: «The Tibetan Buddhist Learning Center is a (non-sectarian) Center dedicated to the study, practice, and preservation of Buddha's teachings. Originally named the Lamaist Buddhist Monastery of America, it was founded in 1958 through the great efforts of Geshe Ngawang Wangyal, a KalmykMongolian guru who received his training in Kalmykia and in Tibet... ${ }^{10}$ [Tibetan Buddhist Learning Center].

Бурная религиозная жизнь американских калмыков и появление высокообразованного священнослужителя в их общине не могли не быть предметом обсуждения с сородичами в европейских странах, где буддийский храм имелся лишь в г. Белграде, но во время второй мировой войны был разрушен и не действовал. Фотография из архива французских калмыков является свидетельством не только связей между калмыцкими диаспорами в США и Франции, но и того, что геше Вангъял совершал поездки к сородичам в Париж и имел тесные контакты с калмыками во Франции.

8 Ученик геше Д. Урубджуров пишет о том, что геше Вангъял попытался присоединиться к общинам храмов Гэмпил Линг и Таши Лумпо, но встретил противодействие, которое выявило «клановые» и «племенные» противоречия [Urubshurow 2013]. Об этом П. Рубел отмечала, что небольшая калмыцкая община США разделилась на три группы согласно субэтнической принадлежности: две группы калмыков-бузавов (в Филадельфии и Хауэлле) и группа калмыков-дербетов и калмыков-торгутов в Хауэлле. «Четвертый блок, ориентированный на академический буддизм, был создан ламой, заинтересованным в продвижении этих аспектов и модернизации буддизма» [Rubel 1967: 111] — речь идет о геше Вангъяле.

${ }^{9}$ Его ученик Д. Хопкинс пишет: «Геше Вангьял был уникален среди других священнослужителей в калмыцкой общине из-за его (самостоятельно освоенного) беглого английского языка и его степени геше в буддийской философии, полученной на факультете Гоман монастыря Дрепунг в Лхасе. Эти факторы вскоре после прибытия привели его к должности преподавателя в университете Колумбии, которая предоставила ему неслыханную в калмыцких духовных кругах России или Соединенных Штатов экономическую и личную независимость. Это также привлекло к нему внимание со стороны разных групп людей, жаждавших соприкоснуться с интеллектуальной, философской и духовной традицией, до того времени недоступной где-либо вне ее гималайского источника» [Хопкинс 2009: 25].

10 'Тибетский буддийский исследовательский центр - (несектантский) центр, посвященный изучению, практике и сохранению учения Будды. Он был изначально назван Ламаистским Буддийским монастырем Америки и был основан в 1958 г. благодаря великим усилиям Геше Нгаванг Вангъяла, калмыцко-монгольского учителя, получившего буддийское образование в Калмыкии и Тибете...'. Здесь и далее перевод автора статьи. 
Вопрос о возможных контактах геше Вангъяла и семьи Зольвановых до «американского» периода жизни буддийского учителя необходимо изучать отдельно, как и вопрос о том, когда состоялась встреча геше Вангъяла с Натали Зембиновой. Так, ученик геше, Д. Урубджуров, пишет, что путь из Индии в США, куда он пытался добиться разрешения на въезд с 1952 г. - с того самого времени, как узнал о поселении в 1951 г. калмыцкой общины в Нью-Джерси, - шел через Францию. Геше неоднократно обращался к американскому консулу в Нью-Дели с просьбами о выдаче визы, и когда в самом конце 1954 г. он получил визу, то добрался до Франции, откуда ему предстояло отплыть на пароходе в Нью-Йорк, куда он прибыл в начале 1955 г. [Urubshurow 2013].

Возможно, что во Франции геше Вангъял встречался с калмыками и в 1954 г. Но фотография с Н. Зембиновой и ее дочерью, судя по возрасту на ней буддийского учителя (с седой бородкой), явно была сделана позже. Вероятно, эта встреча во Франции (в Париже?) состоялась в 1970 г., так как в коллекции сохранилось письмо от учеников геше Вангъяла (имеется подпись «Дебби и Брайан») к их учителю, адресованное геше Вангъялу и отправленное на имя Бетти Оганесян-Зольванов ${ }^{11}$ в августе 1970 г. в Париж, - вероятно, в это время геше находился в Париже у Зольвановых, поскольку авторы пишут, что они рады, что поездка геше проходит хорошо ${ }^{12}$. Исходя из этого факта, можно предположить, что фотография датируется 1970 г. и на ней вместе с геше Вангъялом запечатлены Натали Зембинова-Зольванова и ее дочь Кишегте Зольванова-Оганесян.

В коллекции имеется другая фотография, которая косвенно свидетельствует о контактах, которые могли связывать буддийского учителя и представителей калмыцкой диаспоры в разных странах. Так, в архиве семьи Зольвановых сохранилась уникальная фотография, на которой на фоне буддийского храма Раши Гемпил Линг изображены буддийский монах Шар эмчи и калмык Дорджи Пюрвеев (фото 3). Надпись на обороте снимка (фото 4) гласит, что фотография сделана 1 января 1957 г., а предназначена она была племяннику Д. Пюрвеева по женской линии (калм. зе) - Дарме. Снимок Дорджи Пюрвеев послал племяннику (сыну сестры) Дарме «на долгую память», с подписью «уважающий твой нахцха ${ }^{13}$ ». Таким образом, наличие в коллекции Зольвановых фотографии, подаренной Д. Пюрвеевым племяннику Дарме, свидетельствует о том, что этот самый Дарма имел близкое отношение к семье Натали Зембиновой-Зольвановой.

${ }^{11}$ Вероятно, дочь Кишегте Зольвановой и Паскаля Оганесяна, которые проживали в Париже.

12 Письмо начинается со слов: «Dear geshela kusho _ lama la chak tsal» и завершается словами «lama la chak tsal». Сообщается, что все хорошо, геше Дава Сангпо (буддийский монах, который жил в монастыре Лабсум Шедруб Линг [Геше Вангъял 1993: 27] и, вероятно, болел в 1970 г.) уже лучше. Сообщение о кончине профессора Робинсона предваряется написанием мантры «Ом мани падме хум». Это письмо, которое было адресовано геше Вангъялу и которое он, судя по фотографии встречи с Зольвановыми, прочитал, осталось храниться в архиве семьи французских калмыков. На конверте сохранился обратный адрес: Вашингтон, Нью-Джерси, ретритный дом (Retreat House, Washington, NJ), что свидетельствует: Бетти и Брайан отправили его из ЛБМА, который к тому времени был перенесен в местечко Вашингтон в том же штате.

${ }^{13}$ Калм. наһuхха 'дядя по матери'. 


\section{Источниковедение}

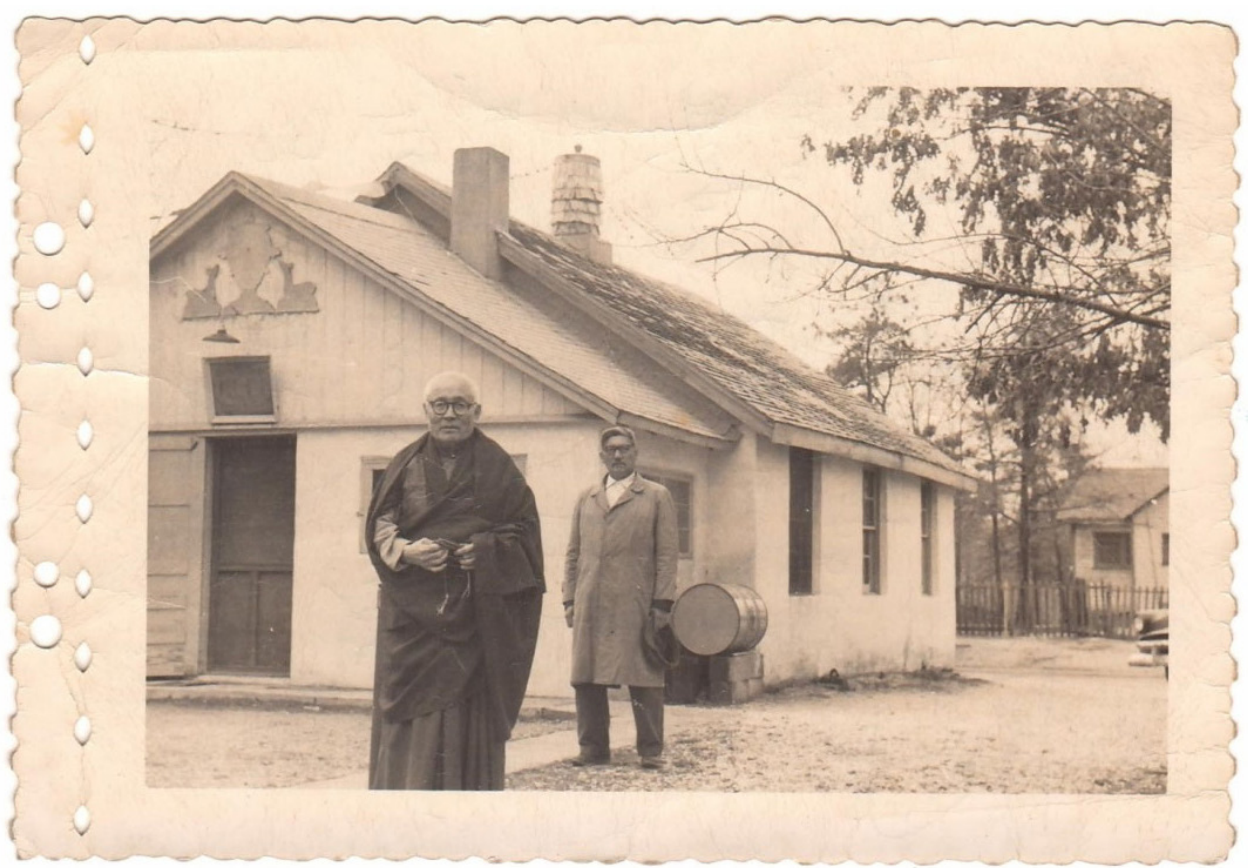

Фото 3. Шар эмчи и Дорджи Пюрвеев у храма. 01.01.1957. Из коллекции семьи Зольвановых

[Photo 3. Ven. Shara Emchi and Dordzhi Pyurviev at the temple. January 1, 1957.

From the Zolvanoff family archive]

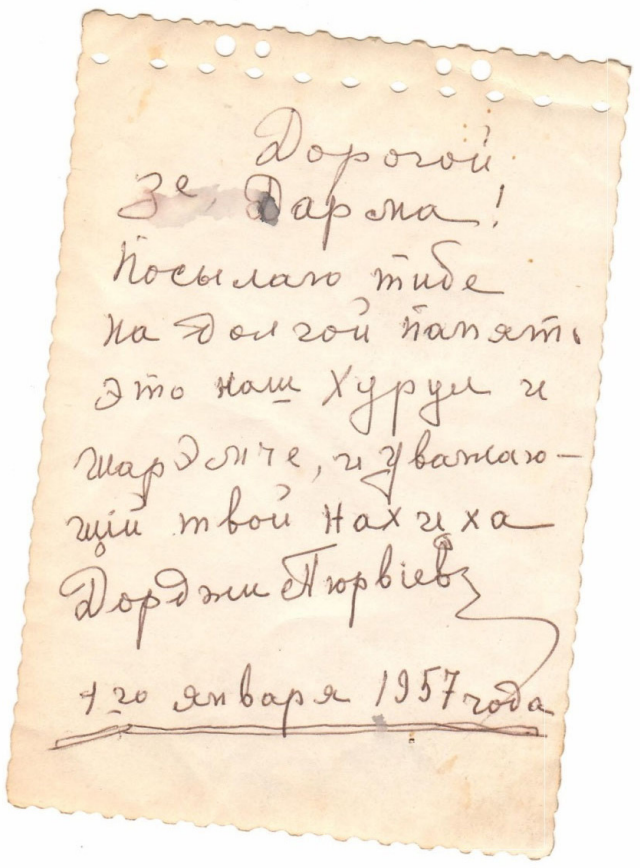

Фото 4. Надпись на обороте фотографии из коллекции семьи Зольвановых. 01.01 .1957

[Photo 4. Inscription at the back of the photo. January 1, 1957. From the Zolvanoff family archive] 
Через Д. Пюрвеева могли осуществляться связи этой семьи с геше Вангъялом, так как, по свидетельству Давида Урубджурова, с 7 лет являвшегося учеником геше в ЛБМА, Дорджи Пюрвеев был другом детства геше Вангъяла. Так, в описании фотографии (фото 5), приведенной в статье Д. Урубджурова, читаем: «Геше Нгаванг Вангьял и друг детства из Калмыкии Дорджи Пюрвиев в новой алтарной комнате Ламаистского буддийского монастыря Америки, 1964 год» [Urubshurow 2013]. На снимке запечатлено особое отношение и расположенность геше Вангъяла к другу детства, а внешнее сходство и совпадение имени и фамилии показывают, что на снимке с буддийским монахом Шар эмчи и на фотографии с геше Вангъялом запечатлен один человек Д. Пюрвеев (или Пюрвиев).

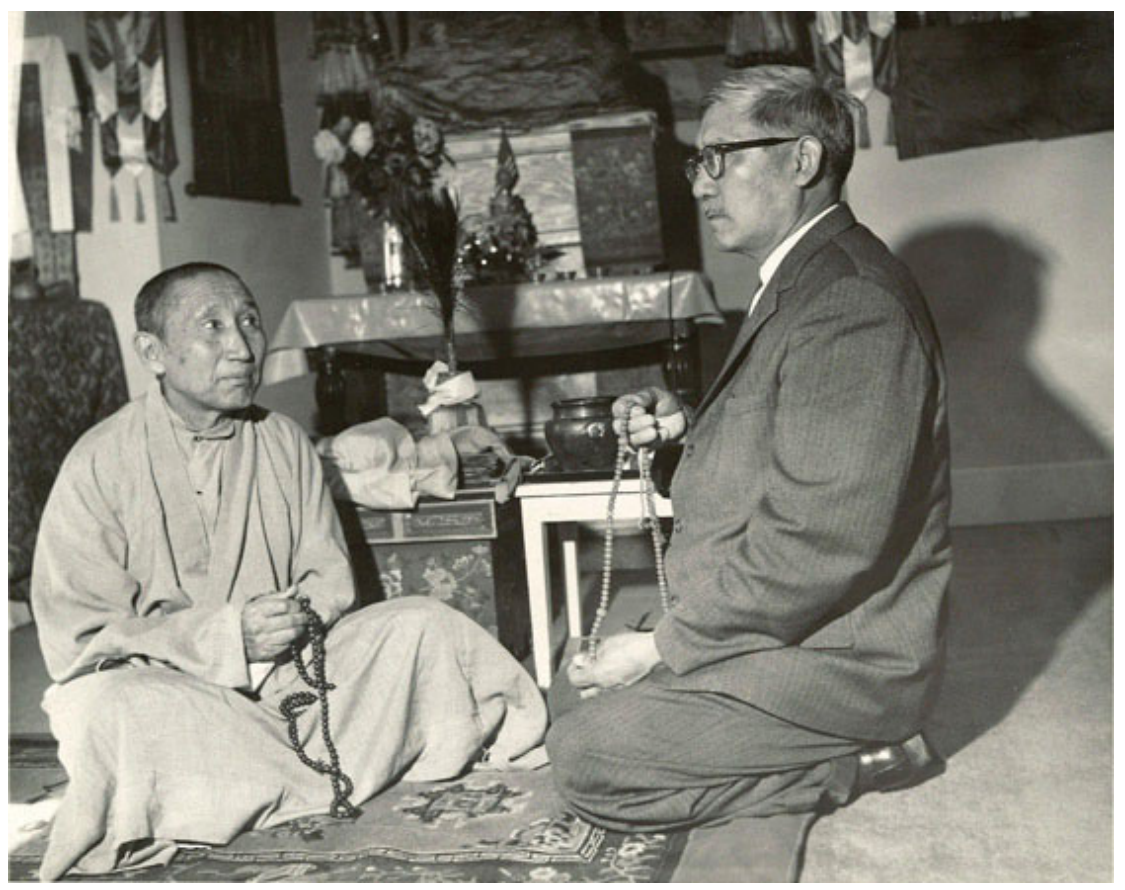

Фото 5. «Геше Нгаванг Вангъял и его друг детства из Калмыкии Дорджи Пюрвиев в новой алтарной комнате Ламаистского буддийского монастыря Америки, 1964 г.». По публикации: [Urubshurow 2013].

[Photo 5. Ven. Geshe Ngawang Wangyal and his childhood friend Dordzhi Pyurviev in the new altar room. Lamaist Buddhist Monastery of America, 1964]

\section{Фотографии Далай-ламы XIV и буддийских священнослужителей из коллекции Зольвановых}

Для верующих буддистов изображение буддийского учителя - предмет поклонения. Этот особый аспект религиозной жизни французских калмыков также отражен в анализируемой коллекции. Так, в архиве Зольвановых имеются три фотографии Далай-ламы XIV Тензин Гьяцо, причем это не простые копии, а официальные фотографии, выполненные одним фотографом и имеющие соответствующие штампы, свидетельствующие об авторских правах на снимки, на обороте: «Сору Right. Office of the Dalai Lama. Tekchen Choling, Dharamsala, India. Photo by Thubten Wullschleger». 


\section{Источниковедение}

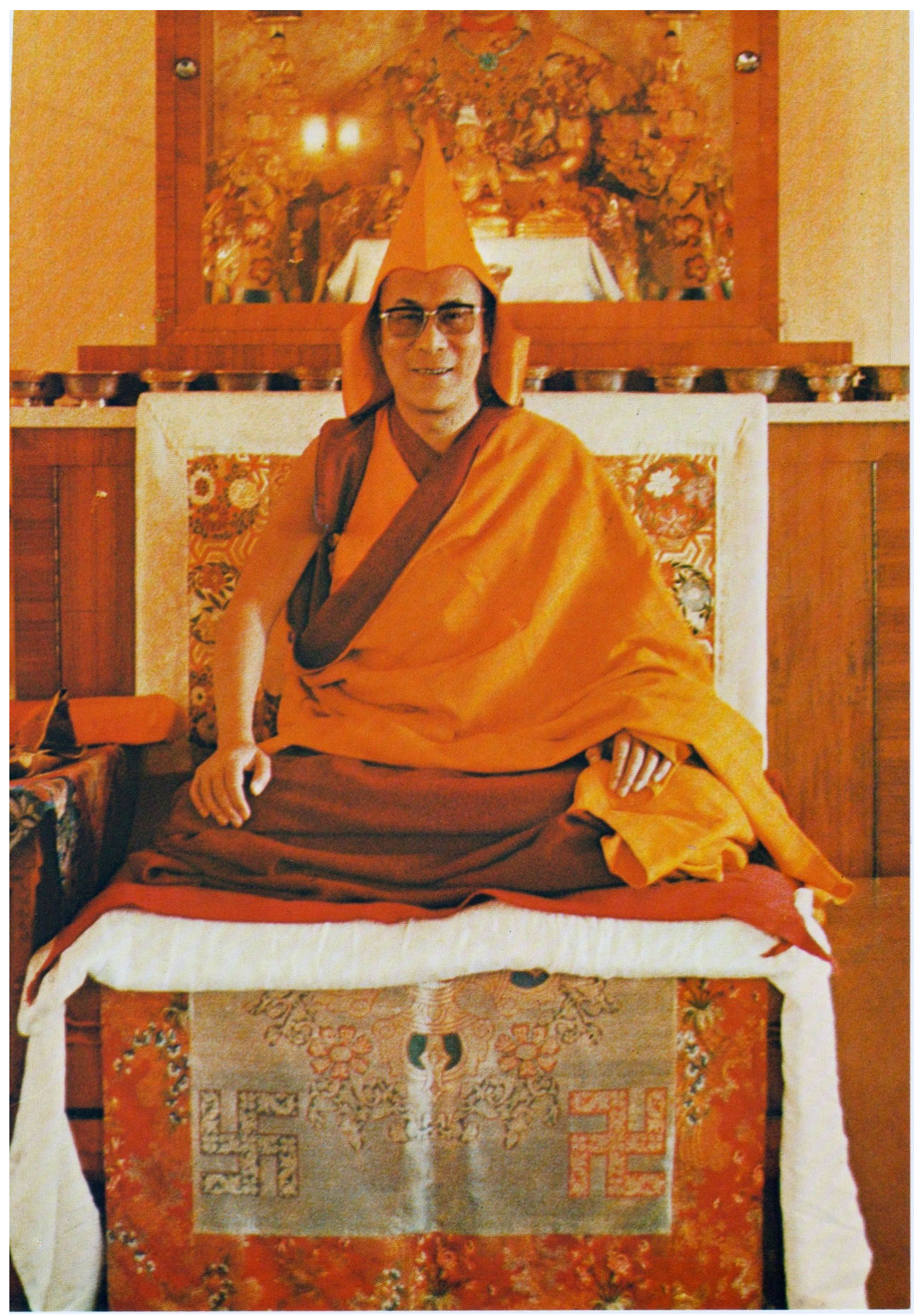

Фото 6. Официальная фотография Далай-ламы XIV из коллекции семьи Зольвановых

[Photo 6. Official photo of His Holiness the $14^{\text {th }}$ Dalai Lama. From the Zolvanoff family archive] 


\begin{tabular}{l} 
COPY RIGHT \\
\hline OFFICE OF THE DALAI LAMA \\
Thekchen Chuli :g. Dharamsala \\
1. DIA.
\end{tabular}

Фото 7. Copy Right на обороте фотографии

[Photo 7. Copy right inscription at the back of the photo]

Две из трех фотографий цветные, одна - черно-белая. На первом цветном снимке Далай-лама запечатлен на его троне, в ламском остроконечном головном уборе (официальное, фото 6, 7), на втором снимке - сидящим вне трона, в медитации (фото 8). На черно-белом снимке Далай-лама изображен медитирующим, с ритуальным предметом в руках (фото 9). Все три фотографии духовного иерарха довольно ранние, они сделаны не позднее 1970-х гг. 


\section{Источниковедение}

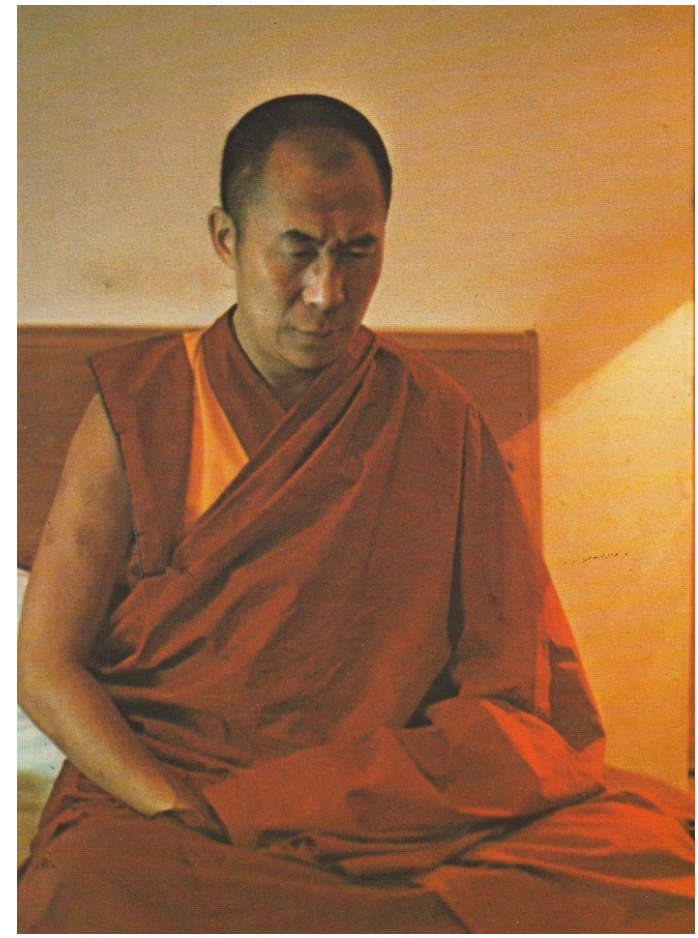

Фото 8. Далай-лама XIV

[Photo 8. His Holiness the $14^{\text {th }}$ Dalai Lama]

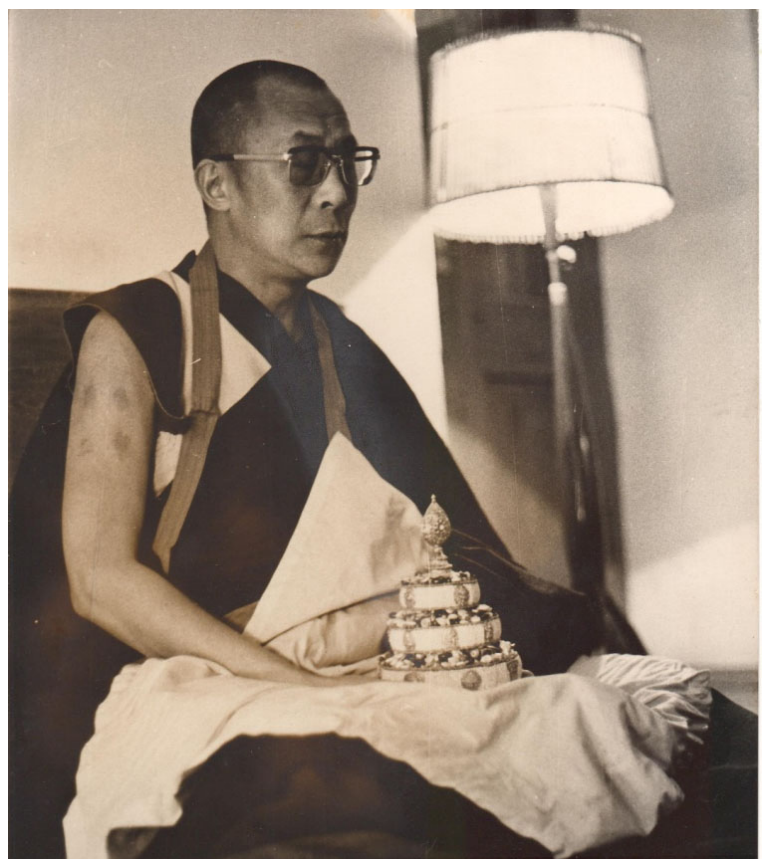

Фото 9. Далай-лама XIV

[Photo 9. His Holiness the $14^{\text {th }}$ Dalai Lama] 
Несомненно, что столь ценные снимки (не копии, а именно оригиналы) были получены семьей французских калмыков от высокопоставленных священнослужителей, которым в условиях ограниченных связей были доступны такие официальные снимки. Вполне вероятно, что оригиналы уникальных фотографий могли быть получены от геше Вангъяла, который состоял в переписке с тибетскими монахами и монастырями в Индии, а также неоднократно совершал паломничество в тибетские монастыри Индии. Так, после 1960 г. геше Вангъял побывал у Далай-ламы, после чего в 1962 г. в ЛБМА Далай-лама послал четырех тибетских монахов; в 1964 г. геше посетил Дхарамсалу, где поселились тибетские беженцы, со своим учеником Р. Турманом, и познакомил его с Далай-ламой XIV. В 1979 г. впервые Далай-лама прибыл в США, где прежде всего побывал в ЛБМА, и в последующем часто совершал поездки в эту страну. Потому предположение об этом источнике появления в коллекции Зольвановых официальных фотопортретов Далай-ламы XIV более чем допустимо.

Калмыки в эмиграции почитали не только монахов, которые являлись учителями в их общинах. Они помнили о прежней буддийской традиции в Калмыкии и буддийских монахах, которым поклонялись их родители. Так, в коллекции Зольвановых имеется копия снимка Ламы донских калмыков Аркада Чубанова (1840-1894; избран Ламой донских калмыков в 1873 г. [Bormanshinov 1991: 6-13; Борманджинов 1997: 13-21]), уроженца Намровской сотни (Платовской станицы), в традиционной широкой по подолу одежде священнослужителя и особом головном уборе «титим» (фото 10). Кроме этой копии, имеются и оригиналы снимков буддийских монахов. Среди них снимок калмыцкого монаха, сделанный в Париже в ателье, сведения о котором размещены на обороте: «Ancienne Maison Graffe R.Rouers, 9, Place St André des Arts, 9, Paris». На фотографии запечатлен уроженец Геленгякинского аймака (станицы Новоалексеевской) - багши Новоалексеевского хурула Дорджи Нимбушов, сидящий в кресле, в одежде калмыцкого служителя, с ритуальным оркимджи ${ }^{14}, \mathrm{c}$ тканевым поясом и с большими четками в руках (фото 11). В том же ателье выполнена была почтовая карточка с изображением калмыцкого монаха - багши станицы Денисовской Джамнина Умальдинова, сидящего в кресле, в одежде священнослужителя ${ }^{15}$ и оркимджи, с тканевым поясом (фото 12). Третья фотография не имеет сведений о месте изготовления, но также явно относится к французскому периоду жизни эмигрантов. На снимке калмыцкий монах, гелюнг Денисовского хурула Басанов Молун Басанович, изображен сидящим в кресле у стола, в его правой руке четки (фото 13). На обороте просматривается надпись «От Моло...», что позволяет предположить, что фотография имела дарственную подпись.

${ }^{14}$ В тибетской буддийской традиции оркимджи является ритуальной накидкой. Но на фотографиях калмыцких монахов первой четверти XX в. оркимджи имеют вид сложенной в виде длинного шарфа плотной ткани.

${ }^{15}$ Примечательно, что одежда священнослужителей, запечатленных на фотографиях, изготовленных во Франции (на снимке М. Басанова нет сведений об ателье, но виден штамп - надпись на французском языке «Quqlite» ‘качество'), несколько отличается от одежды, которая встречается на фотографиях священнослужителей более раннего периода, где распашная одежда монахов типа лавшиг - более широкая. 


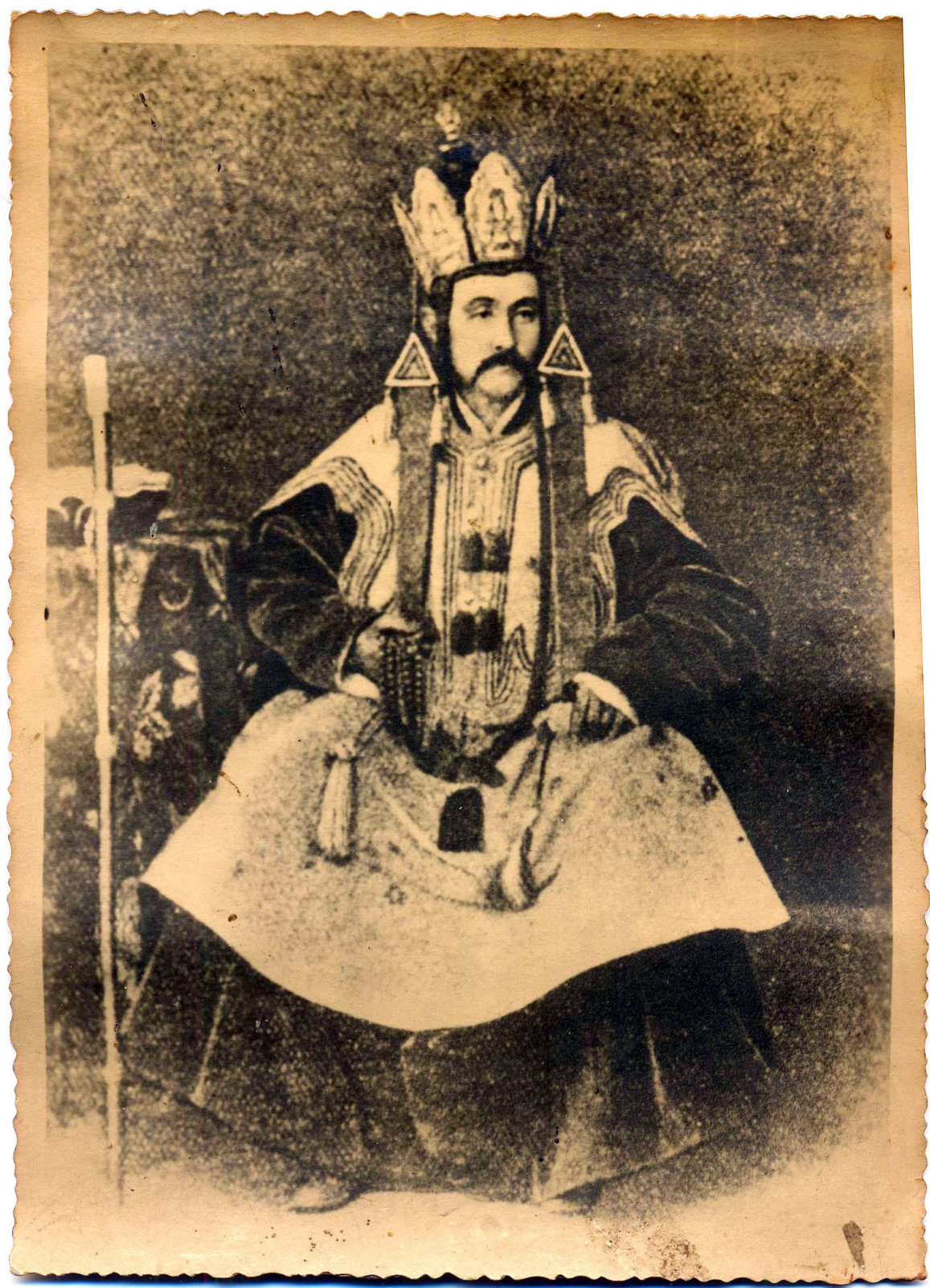

Фото 10. Лама донских калмыков Аркад Чубанов (1840-1894). Фото из коллекции Зольвановых

[Photo 10. Ven. Arkad Chubanov (1840-1894), Lama of the Don Kalmyks. From the Zolvanoff family archive] 
Монголоведение • Mongolian Studies • $2021 \bullet$ T. 13 • № 3

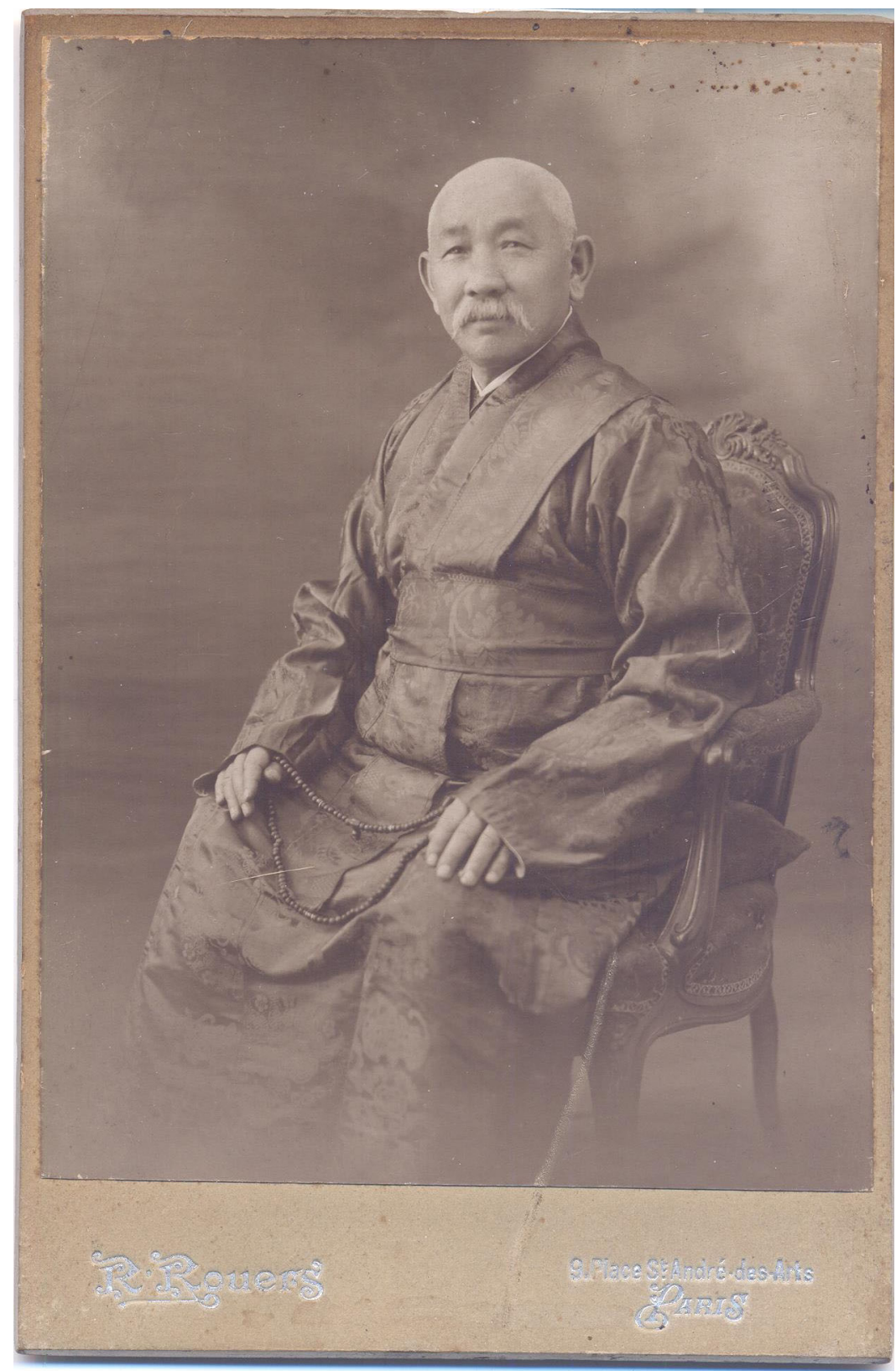

Фото 11. Багши Новоалексеевского хурула Дорджи Нимбушов. Фото из коллекции Зольвановых

[Photo 11. Ven. Dordzhi Nimbushov, Bagshi at Novoalekseevskaya Khurul. From the Zolvanoff family archive] 


\section{Источниковедение}

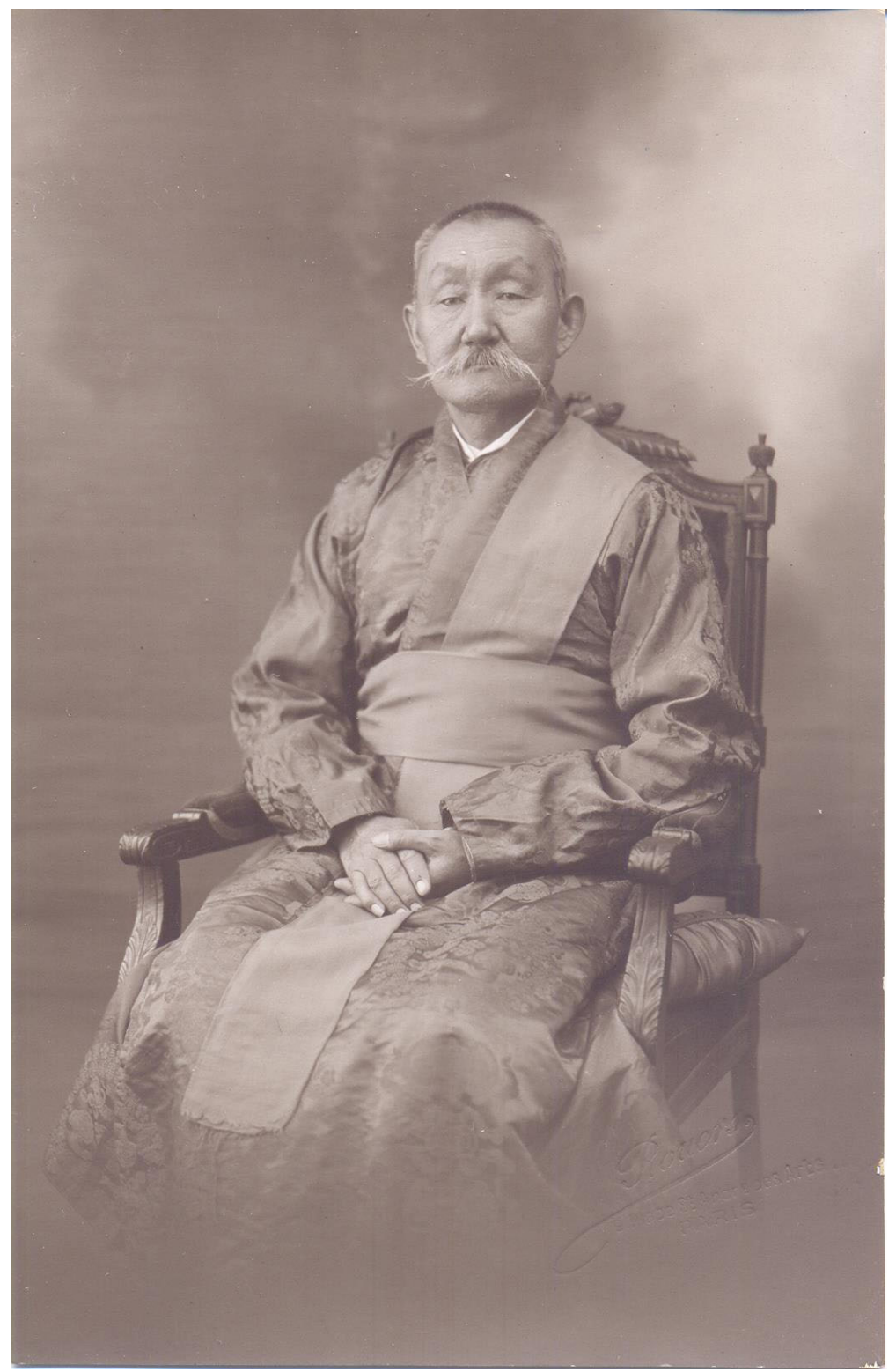

Фото 12. Багши станицы Денисовской Джамнин Умальдинов. Фото из коллекции Зольвановых

[Photo 12. Ven. Dzhamnin Umaldinov, Bagshi at Denisovskaya Khurul. From the Zolvanoff family archive] 


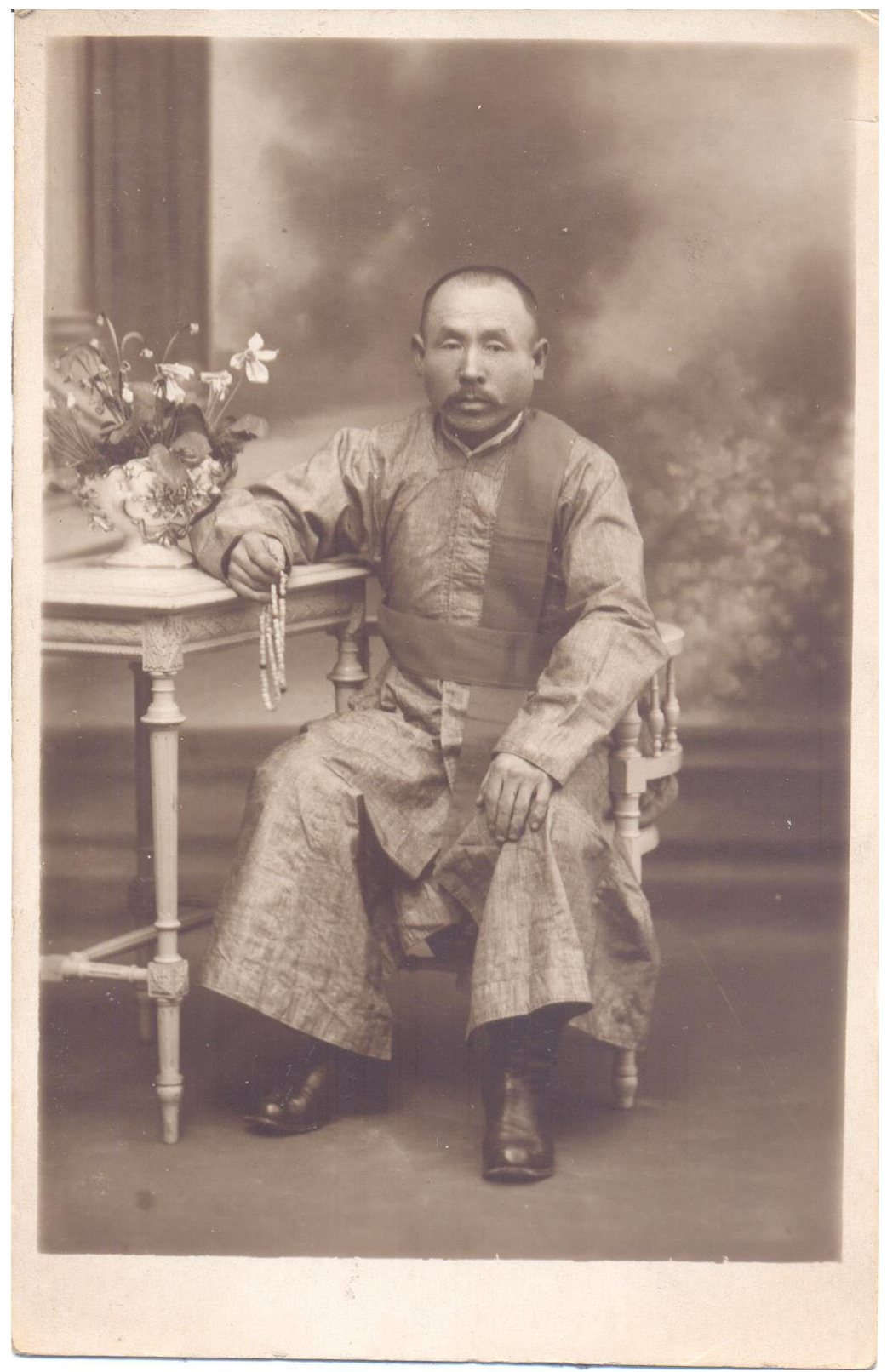

Фото 13. Гелюнг Денисовского хурула Басанов Молун Басанович. Фото из коллекции Зольвановых

[Photo 13. Ven. Molun B. Basanov, gelong at Denisovskaya Khurul. From the Zolvanoff family archive]

Таким образом, на четырех снимках из коллекции Зольвановых изображены монахи - уроженцы разных станиц донских калмыков, что свидетельствует о связях семьи французских калмыков с донскими калмыками-бузавами. На еще одном снимке запечатлен, как отмечалось выше, Шар эмчи - монах из дербетского рода манджикины [Манджиев 2016], проживавший в эмиграции в США до 1970-х гг. 


\section{Источниковедение}

Кроме официальных фотографий священнослужителей (ламы донских калмыков, Шар эмчи, геше Вангъял), в коллекции Зольвановых имеется семь фотографий геше Нгаванг Вангъяла разных лет (цветных и черно-белых). На них запечатлен сам геше Вангъял у Статуи Свободы (фото 14) и на набережной в Нью-Йорке (фото 15), а также у стены Ламаистского буддийского монастыря Америки - в монгольской традиционной одежде типа «дели» (фото 16).

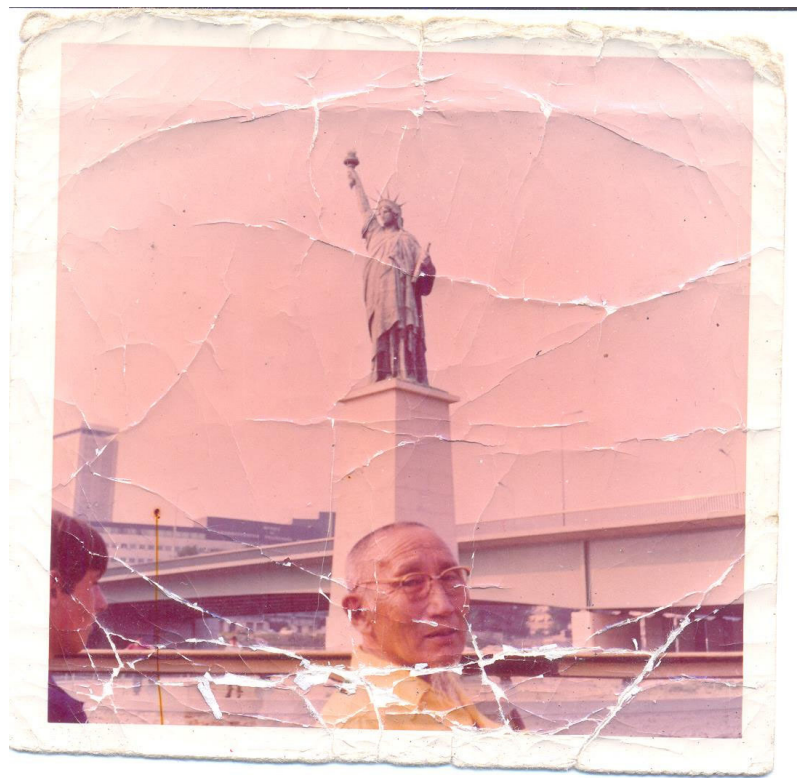

Фото 14. Геше Вангъял у статуи Свободы в Нью-Йорке [Photo 14. Geshe Wangyal at the Statue of Liberty, New York]

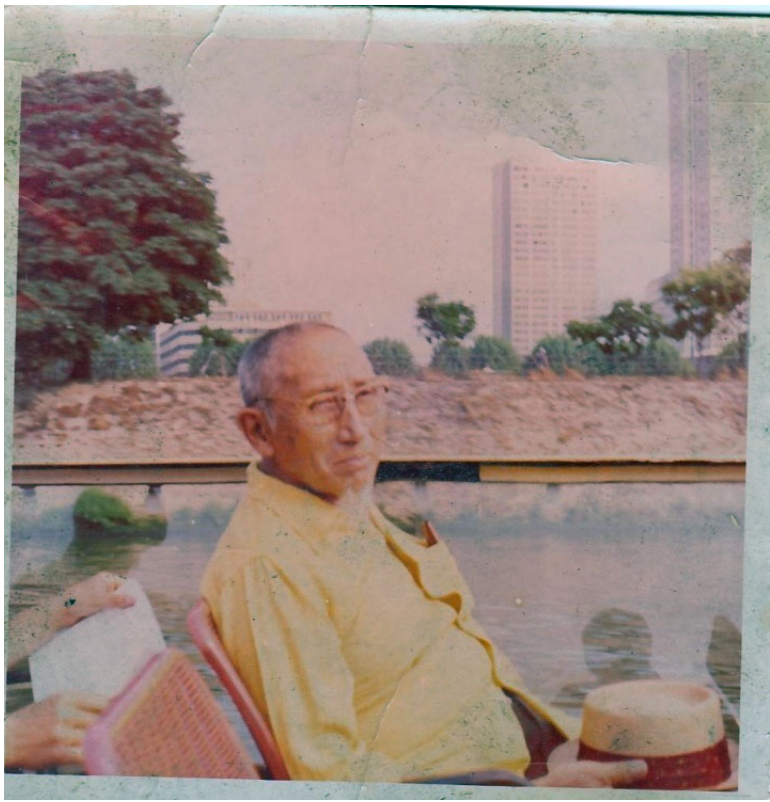

Фото 15. Геше Вангъял в Нью-Йорке [Photo 15. Geshe Wangyal in New York] 
Монголоведение • Mongolian Studies • 2021 • Т. 13 • № 3

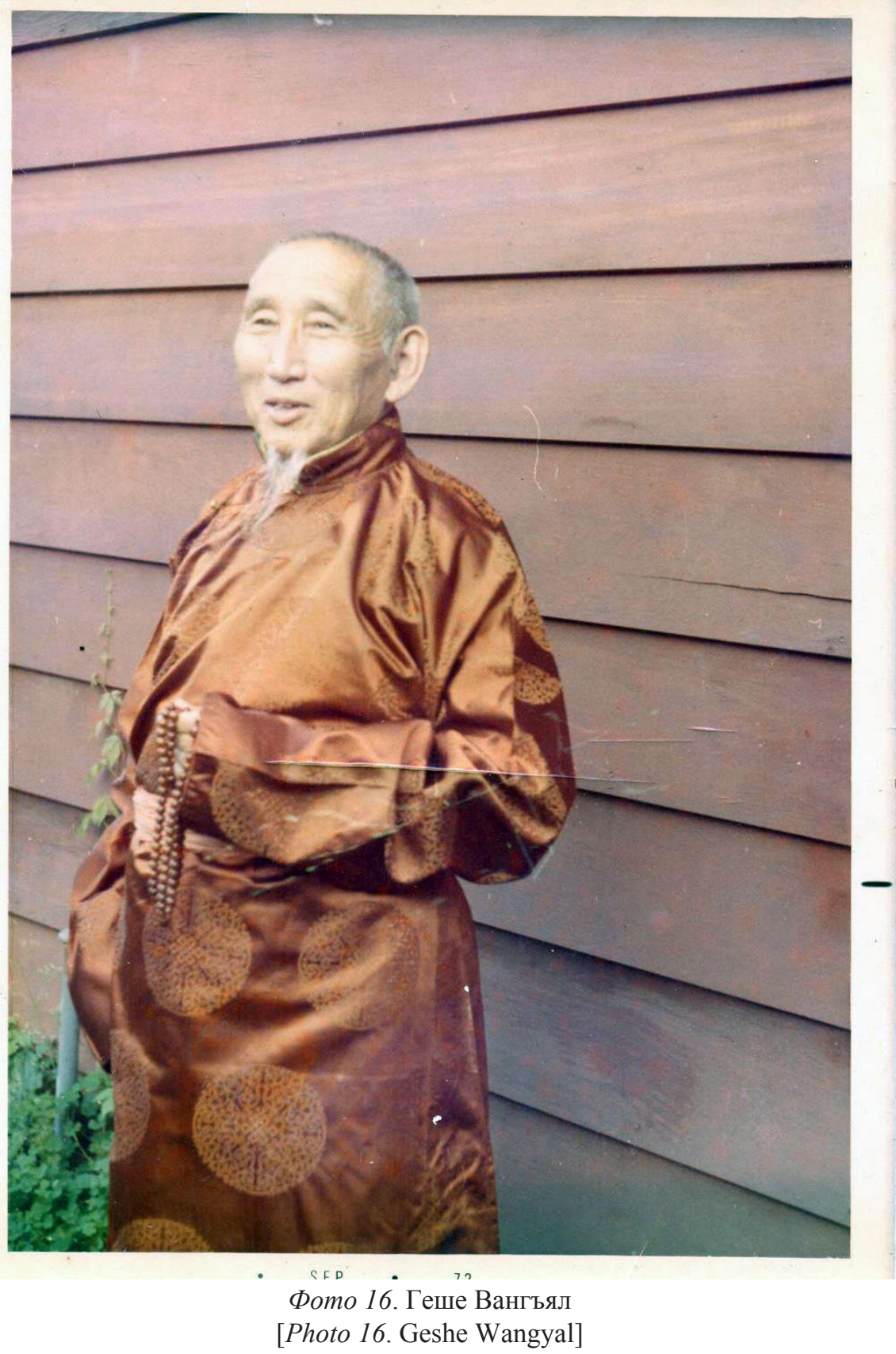

Кроме того, на трех цветных снимках геше Вангъял изображен вместе с учениками: с мальчиком-послушником в традиционной одежде типа лавщиг (Д. Урубжуровым?) (фото 17); с молодым монахом в традиционной одежде тибетского священнослужителя (фото 18); а также среди группы монахов и учеников (фото 19) на фоне ЛБМА (рядом с геше — два монаха, мальчикпослушник (Д. Урубджуров?) и два ученика, один из которых - Д. Хопкинс. На черно-белом снимке также геше Вангъял изображен с учениками (фото 20). 


\section{Источниковедение}

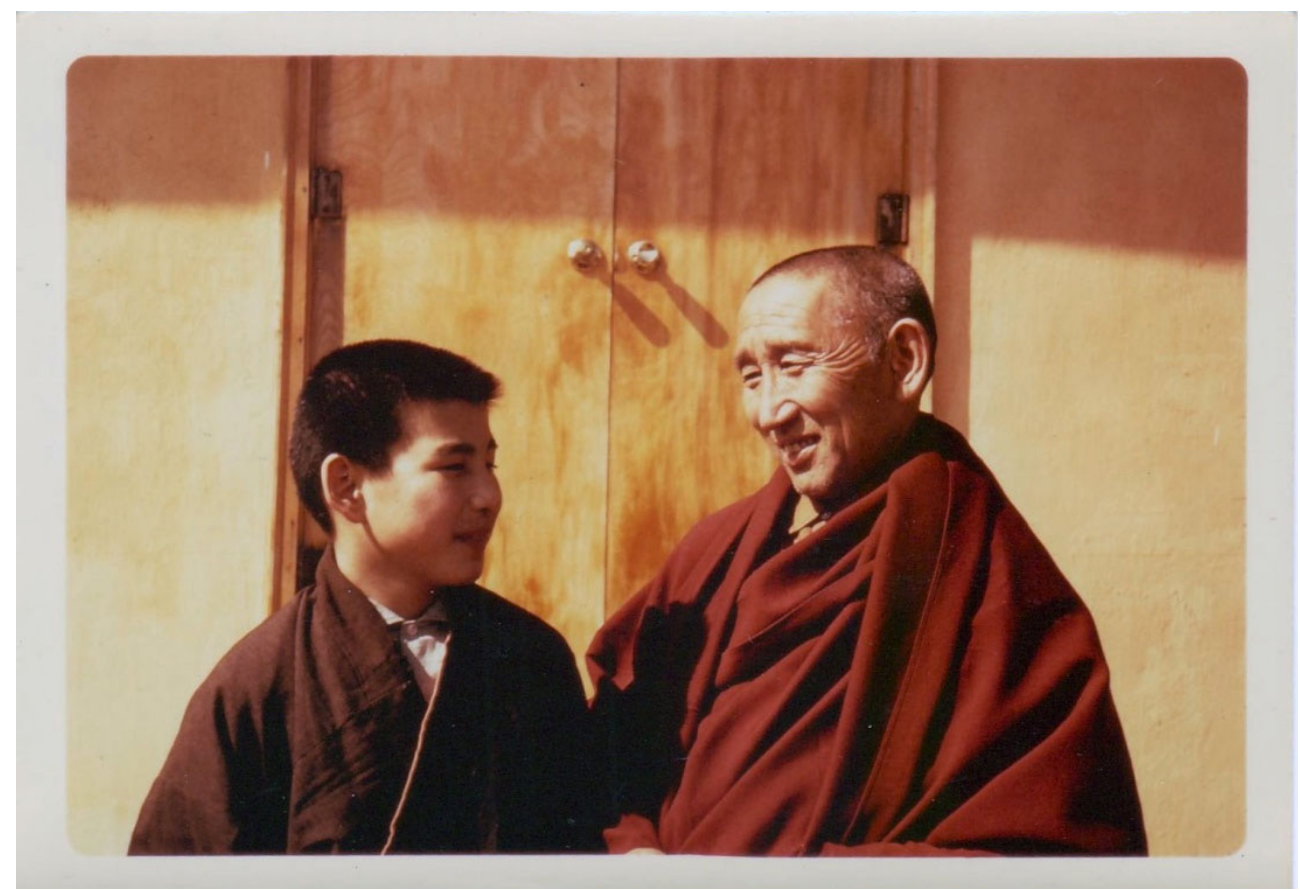

Фото 17. Геше Вангъял с учеником (Д. Урубжуровым?)

[Photo 17. Geshe Wangyal and his disciple (D. Urubshurow?)]

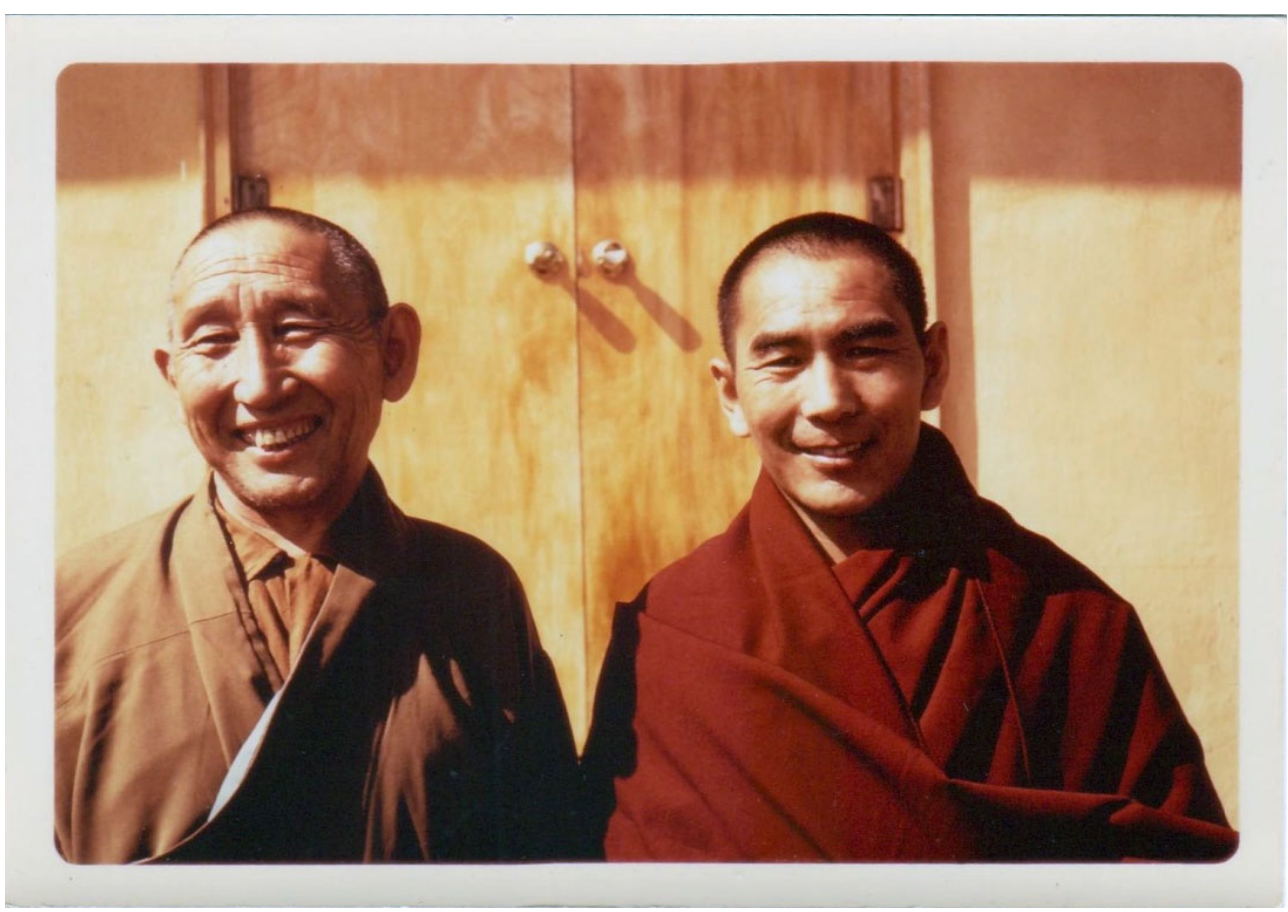

Фото 18. Геше Вангъял и молодой монах

[Photo 18. Geshe Wangyal and a young monk] 
Монголоведение • Mongolian Studies • $2021 \bullet$ T. 13 • № 3

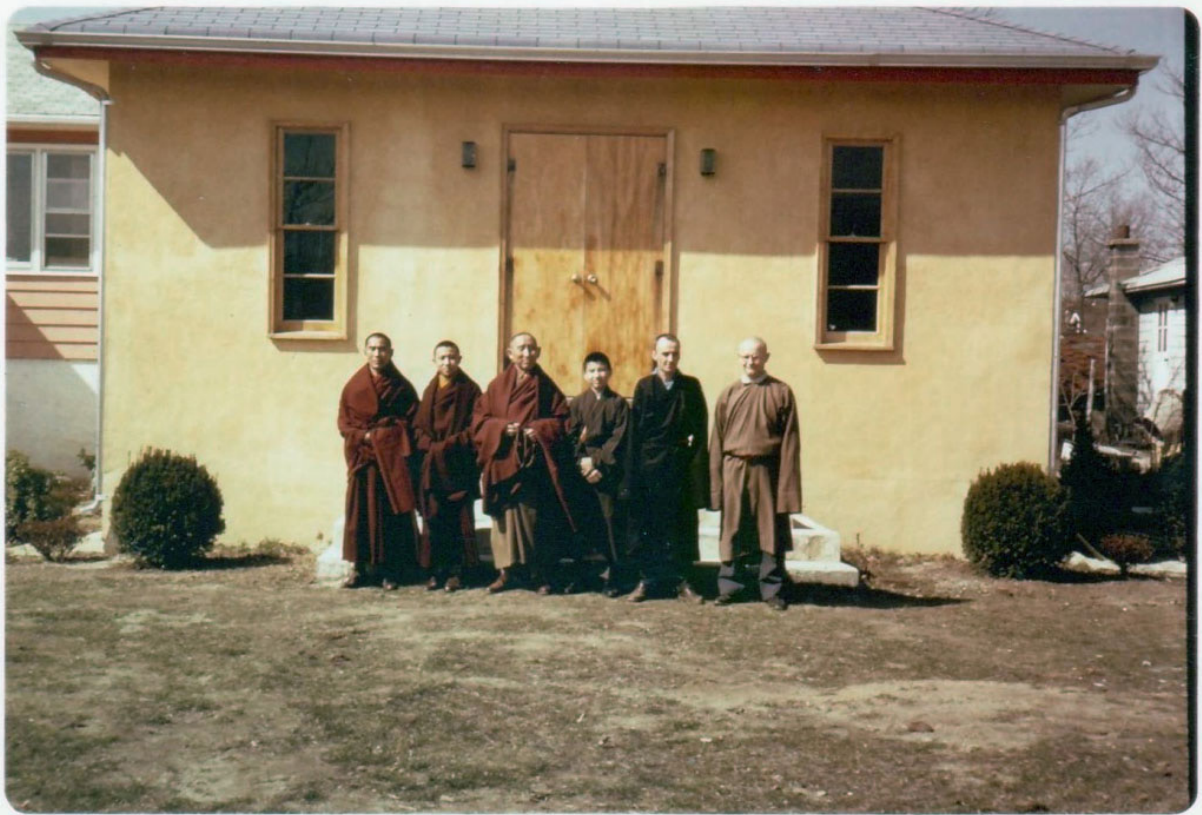

Фото 19. Геше Нгаванг Вангъял с монахами и учениками около ЛБМА

[Photo 19. Geshe Ngawang Wangyal with monks and disciples in front of the LBMA building]

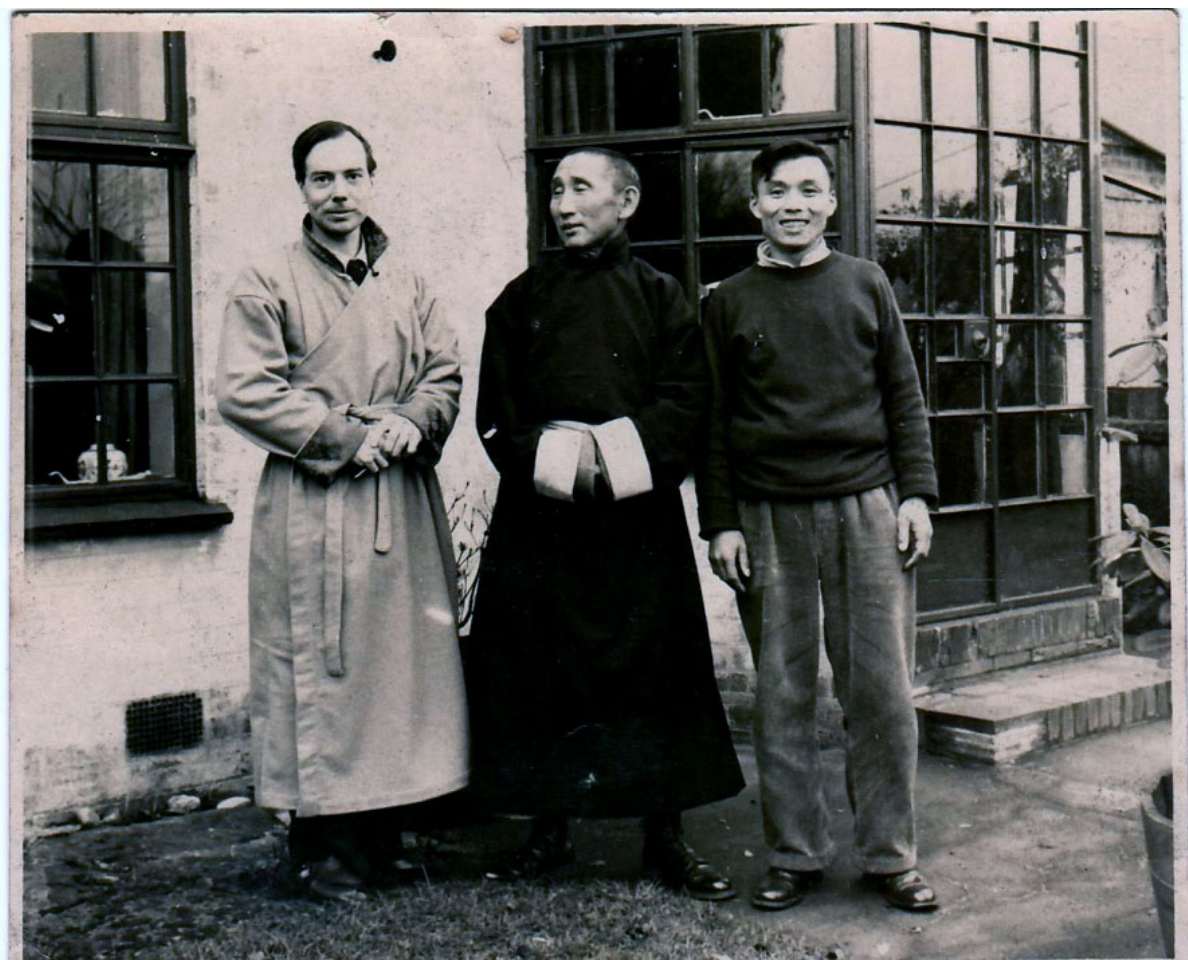

Фото 20. Геше Вангъял с учениками

[Photo 20. Geshe Wangyal and his disciples] 


\section{Источниковедение}

Судя по имеющейся в архивной коллекции переписке геше Вангъяла с семьей французских калмыков, фотографии, на которых изображен высокопоставленный калмыцкий священнослужитель и его ученики, были получены семьей Зольвановых от самого геше. Факт наличия в коллекции Зольвановых фотографий как Ламы калмыцкого народа, возглавлявшего сангху донских калмыков еще в XIX в., так и калмыцких монахов, попавших в эмиграцию и представлявших разные субэтнические группы калмыков и разные станицы донских калмыков, - свидетельство о том, что в семье калмыцких мигрантов во Франции почитали священнослужителей из разных регионов, а особым почетом пользовался геше Вангъял.

\section{Фотографии храмов, предметов культа и письма в коллекции Зольва- новых}

В коллекции имеются изображения буддийских храмов. Так, раритетная аутентичная открытка представляет «Проект буддийского храма в Белграде», на обороте которого - надпись на старокалмыцкой письменности «тодо бичиг» 'ясном письме' и подпись кириллицей: «Чемпель Басанов». Другой снимок - фотокопия свитка с изображением Поталы.

Большая часть анализируемой архивной коллекции представляет изображения буддийских божеств. В условиях изоляции от остального буддийского мира французские калмыки, зачастую не имея возможности иметь оригинальные предметы буддийского культа, довольствовались копиями изображений. Особо ценными в условиях жизни в эмиграции и малодоступности предметов культа являлись оттиски текстов молитв и репродукции. Каждый предмет имел большую ценность как предмет поклонения, и среди них - как многочисленные фотографии буддийских танка, по которым можно судить о предметах буддийского культа в храмах американских калмыков, так и оттиски и репродукции буддийских танка, которые издавались в разные годы, в том числе в серии открыток, посвященных тибетской традиции - к примеру, открытка с изображением Авалокитешвары и надписью «Om Mani Padme hum hri», на обороте имеются надпись «Tibetan Tanka Reproductions» и текст об издании серии открыток, посвященных тибетской традиции, издателем «Dharma Publishing» в Калифорнии.

В связи с необходимостью обеспечения верующих предметами культа и дефицитом буддийских атрибутов представители диаспоры обменивались фотографиями буддийских живописных полотен с изображениями божеств. Так, в коллекции Зольвановых имеется конверт с пометкой «Many pictures of Buddhas in our temple» ('Много изображений будд в нашем храме'), в котором французским калмыкам были направлены фотографии буддийских божеств из буддийского храма в США, - вероятно, из ЛБМА.

Благодаря переписке семьи Зольвановых в их архиве имеются уникальные письма, полученные от культурного общества Гелугпа и буддийских монахов, открытки (в числе которых и рисованные), в том числе предназначенные геше Вангъялу и геше Дава Сампо, отправленные в адрес Ламаистского буддийского монастыря Америки. Ряд писем представляют собой поздравления, направленные из тибетских монастырей Индии разным лицам. Так, открытка с поздравлением с новым 1970 годом, направленная из тибетского монастыря 
на имя господина Лешара, является свидетельством уровня полиграфии, доступной тибетским монахам в этот период: открытка представляет собой рисованное изображение с вшитыми в картонную обложку листами для письма (фото 21).

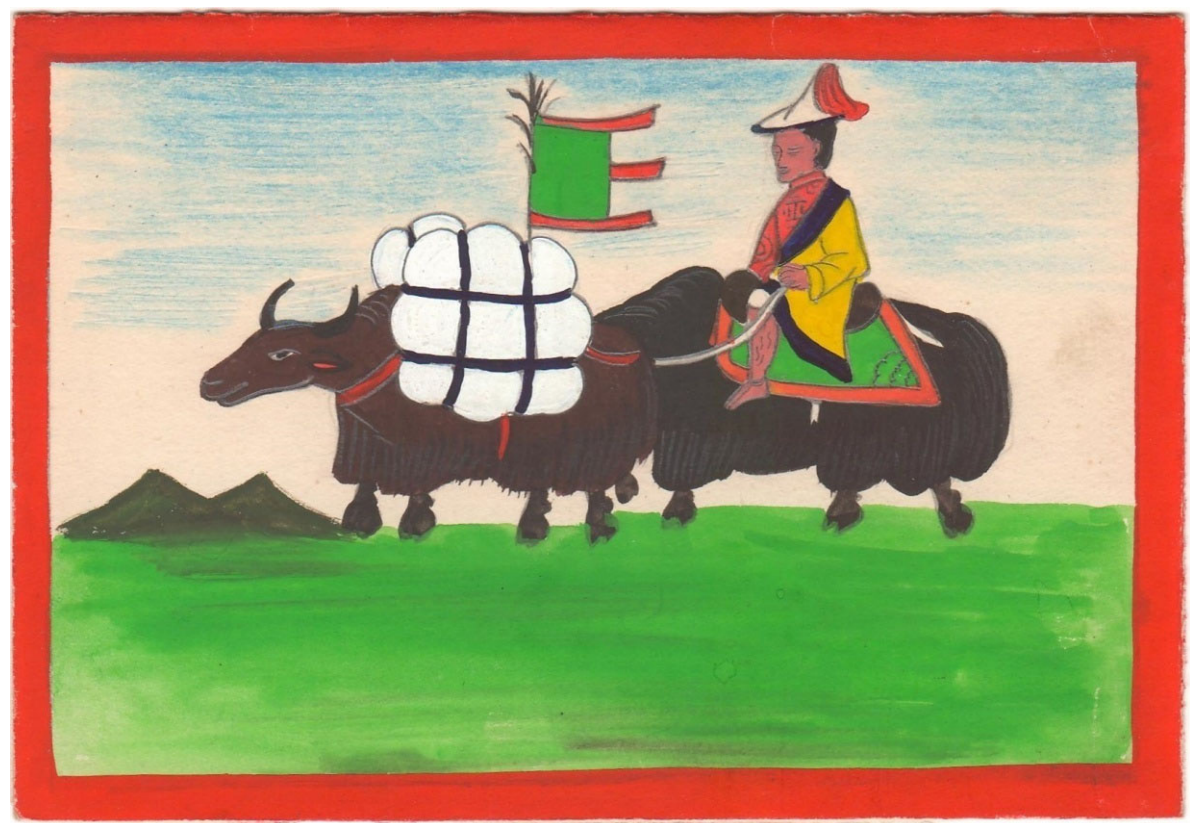

Фото 21. Обложка открытки, направленной 19.12.1969 с поздравлениями

г. Т. Т. Лешару (текст открытки - на английском и тибетском языках)

[Photo 21. Greeting card for Mr. T. Leshar dated December 19, 1969 (in English and Tibetan)]

Среди писем в анализируемой коллекции три имеют особое значение. Одно из них отправлено из Ламаистского буддийского монастыря Америки (ЛБМА), оно написано на бланке монастыря, имевшем изображения колеса учения и ланей и подпись «Labsum Shedrub Ling Lamaist Buddhist Monastery of America, R.D.S. Box 140 (цифры «140» написаны ручкой поверх зачеркнутых «69C»), Parmingdale, New Jersey), и вложено в конверт с этой же символикой. В письме сообщается, что подарок от геше Вангъяла будет передан мадам Зольвановой через Николя Чанчинова (указывается его адрес). Таким образом, письмом, отправленным на имя мужа Нади Зольвановой - Н. Чанчинова, направлялся для Натали Зембиновой-Зольвановой подарок - сложенные в конверт фотографии, сделанные около Ламаистского Буддийского монастыря в Америке (ЛБМА), на которых запечатлен геше Вангъял и его ученики (фото 17, 18, 19, 20), а также фотоснимок скульптуры Авалокитешвары в храме. 


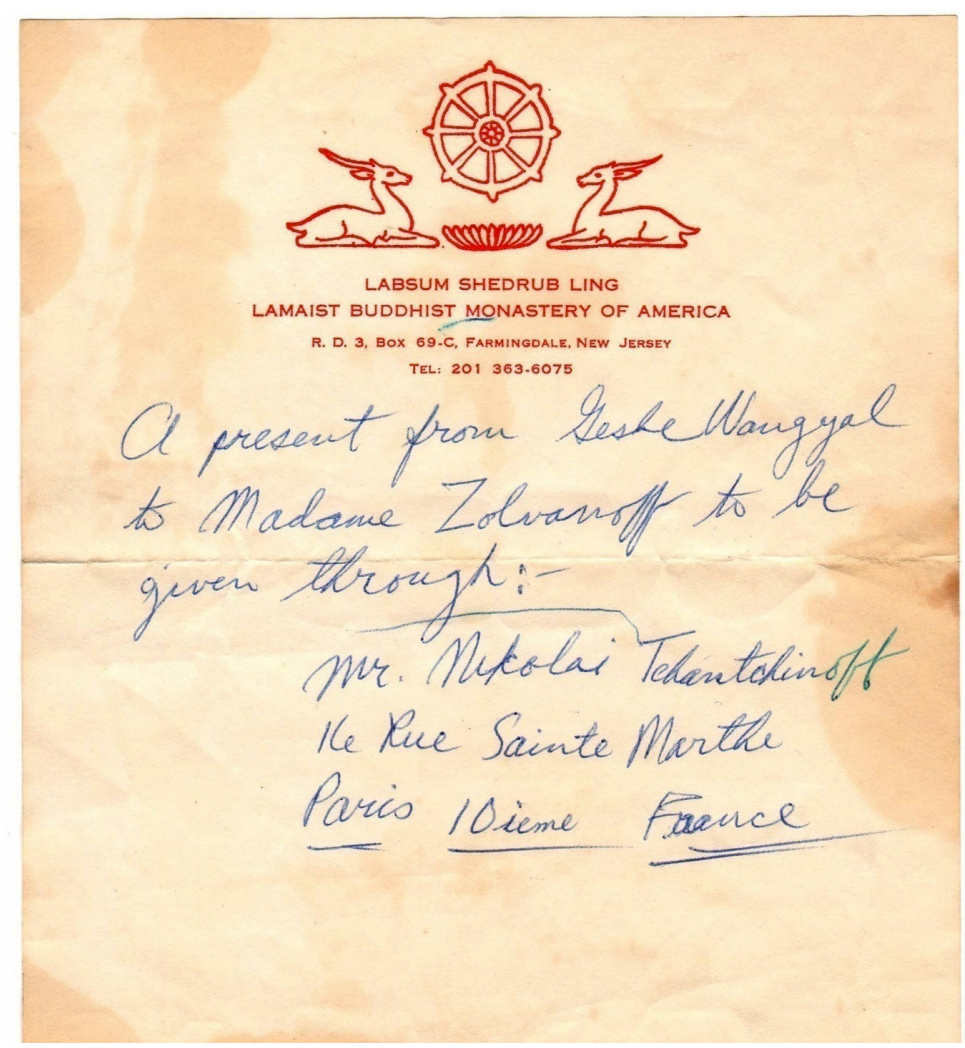

Фото 22. Письмо от геше Вангъяла на бланке монастыря Лабсум Шедруб Линг [Photo 22. Letter by Geshe Wangyal on headed paper of Labsum Shedrub Ling Monastery]

Можно предположить, что письмо могло быть написано самим геше Вангъялом. Однако стиль письма в виде сообщения свидетельствует, что оно было написано кем-то из ближайшего окружения геше.

Но в коллекции имеется автограф самого геше Вангъяла. Речь идет о письме буддийского монаха, отправленном в Париж, в котором он поздравляет с Новым годом семью Зольвановых. Примечательна форма письма, написанного на желтой бумаге с оттиском изображения Будды Шакьямуни с двумя учениками: штампованное изображение занимает четверть листа и расположено так, чтобы внутри сложенного вчетверо листа могло бы быть написано письмо. Таким образом, письмо является ценным свидетельством эпистолярной культуры буддистов XX в. Текст письма: «Нарpy New Year to all of you, I am glad you received the small gift, and I wanted to tell Mme Zolvanov I like to give one prayer wheel of silver. Let me know if any problem to send it in France. With best wishes, Nikolai, Noel ${ }^{16}[i]$ [?] to old mother, Geshe Wangyal» ${ }^{17}$.

${ }^{16} \mathrm{~B}$ этом месте текст письма не ясен. Судя по почерку, можно предположить, что речь идет о поздравлении с Рождеством, которое геше просил передать матери Николая. В тексте прослеживается написание «Noeli», поэтому можно предположить, что речь идет о названии праздника Рождества: англ. «Noel», франц. «Noёl» (и имеет место описка - лишняя буква).

17 'Поздравляю с Новым годом всех вас, я рад, что вы получили маленький подарок, и я хотел сказать мадам Зольванов, что я хотел подарить ей серебряное молит- 
Но, помимо того, что письмо представляет особенности эпистолярной культуры буддийских монахов, оно ценно тем, что в нем имеется автограф геше Вангъяла и оно написано полностью этим известным буддийским монахом.

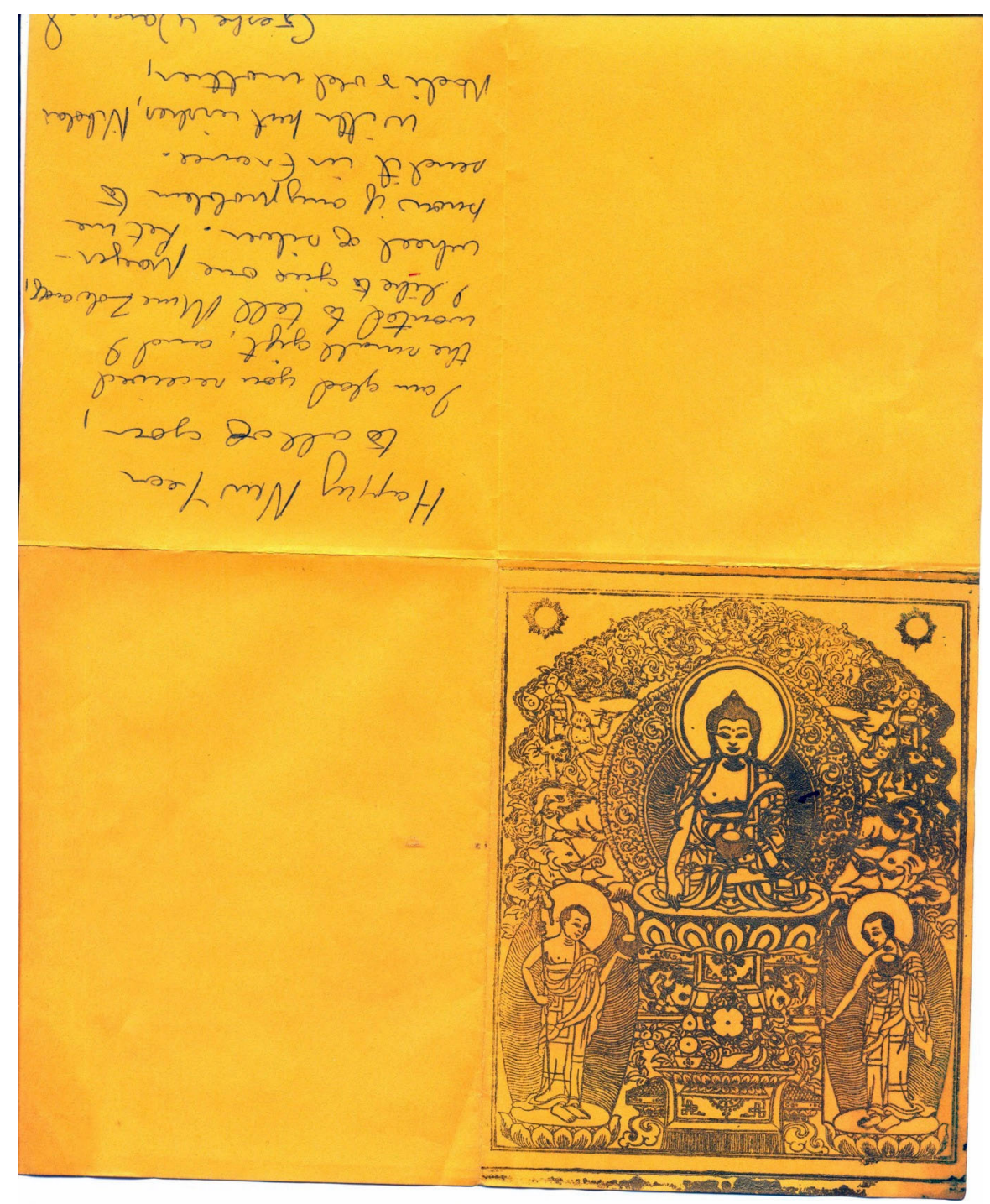

Фото 23. Письмо геше Вангъяла Зольвановым. Общий вид листа с изображением Будды Шакьямуни и его учеников и текстом письма

[Photo 23. Geshe Wangyal's letter to the Zolvanoffs.

The paper depicts Buddha Shakyamuni and his two leading disciples]

венное колесо [кюрде]. Дайте мне знать, если будет проблема послать его [кюрде] во Франции. С наилучшими пожеланиями, Николай, поздравьте с Рождеством [? - текст неясно написан] старую маму. Геше Вангъял'. 


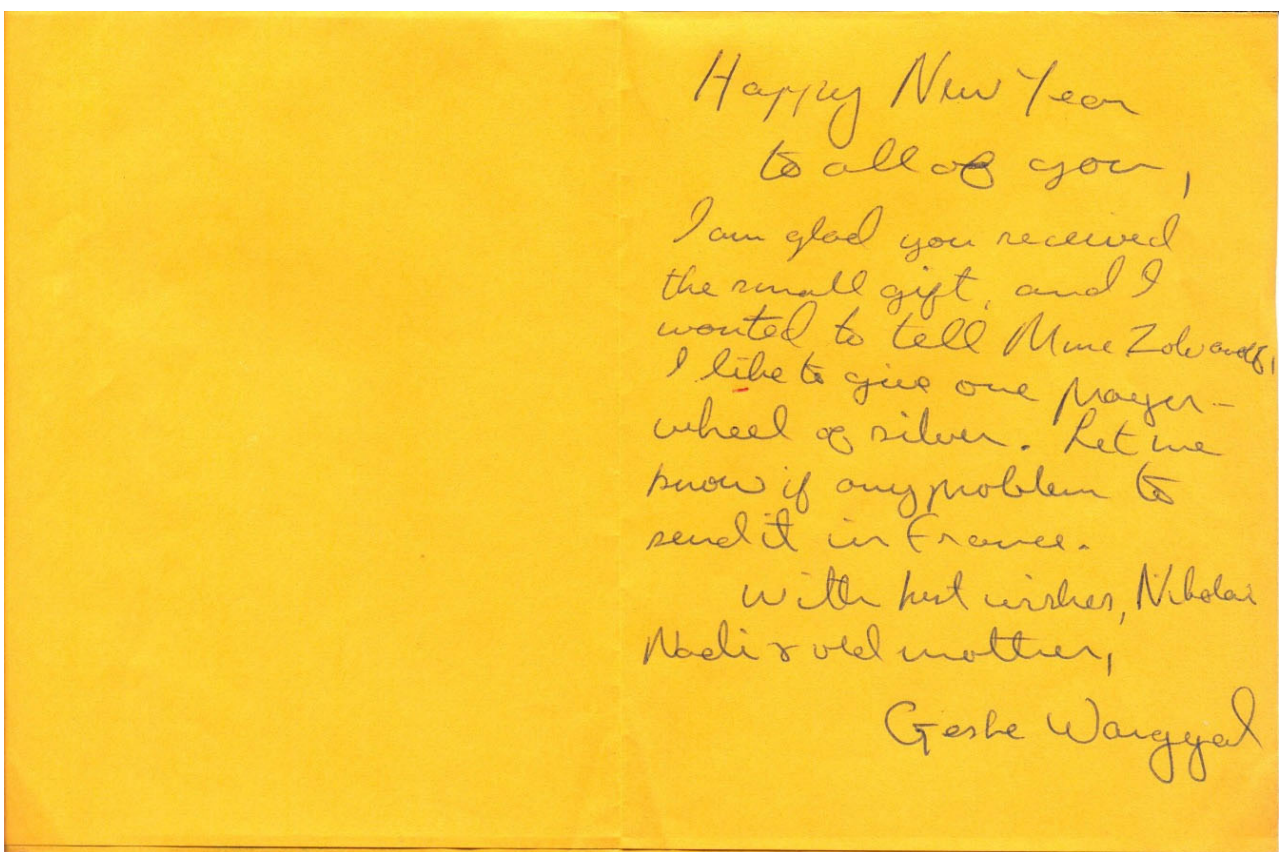

Фото 24. Письмо, написанное геше Вангъялом и содержащее его автограф [Photo 24. Letter by Geshe Wangyal containing his autograph]

Уникальным в коллекции Зольвановых является и письмо на тибетском языке на бумаге с изображением герба Тибета, с подписью «Дворец Ганден, победоносный во всех сторонах» — официального названия тибетского правительства, которое впоследствии было переименовано в Центральную тибетскую администрацию. Письмо получено от Центральной тибетской администрации, оно имеет оттиск малой печати Далай-ламы. Официальное письмо содержит текст, в котором говорится, что от верующей Кермен было получено подношение в виде золота: «В покои Далай-ламы от верующей Кермен было получено подношение в виде одной малой золотой монеты (тиб. gser zam). Мы молимся о том, чтобы в близком и далеком будущем [её] накопление блага преумножилось. С почтением, [Малая печать Далай-ламы]» ${ }^{18}$.

Таким образом, это официальное письмо свидетельствует о том, что между представителями калмыцкой диаспоры и тибетскими монастырями в Индии имелись контакты, и подношения калмыков-буддистов могли быть доставлены по назначению - вплоть до самого Далай-ламы XIV.

\section{Заключение}

Коллекция семьи Зольвановых — ценный источник для изучения истории калмыцкого буддизма. Она представляет материалы для исследования буддийской традиции среди калмыцкой диаспоры - в период, когда в СССР официально не было зарегистрировано ни одной калмыцкой буддийской общины и не действовал ни один калмыцкий храм. Активная религиозная жизнь калмыцкой диаспоры свидетельствует о сохранении буддийской традиции в критических условиях, а также о взаимосвязях между разными «анклавами» диаспоры в разных концах света.

${ }^{18}$ Выражаю благодарность Б. Л. Митруеву за перевод текста письма. 


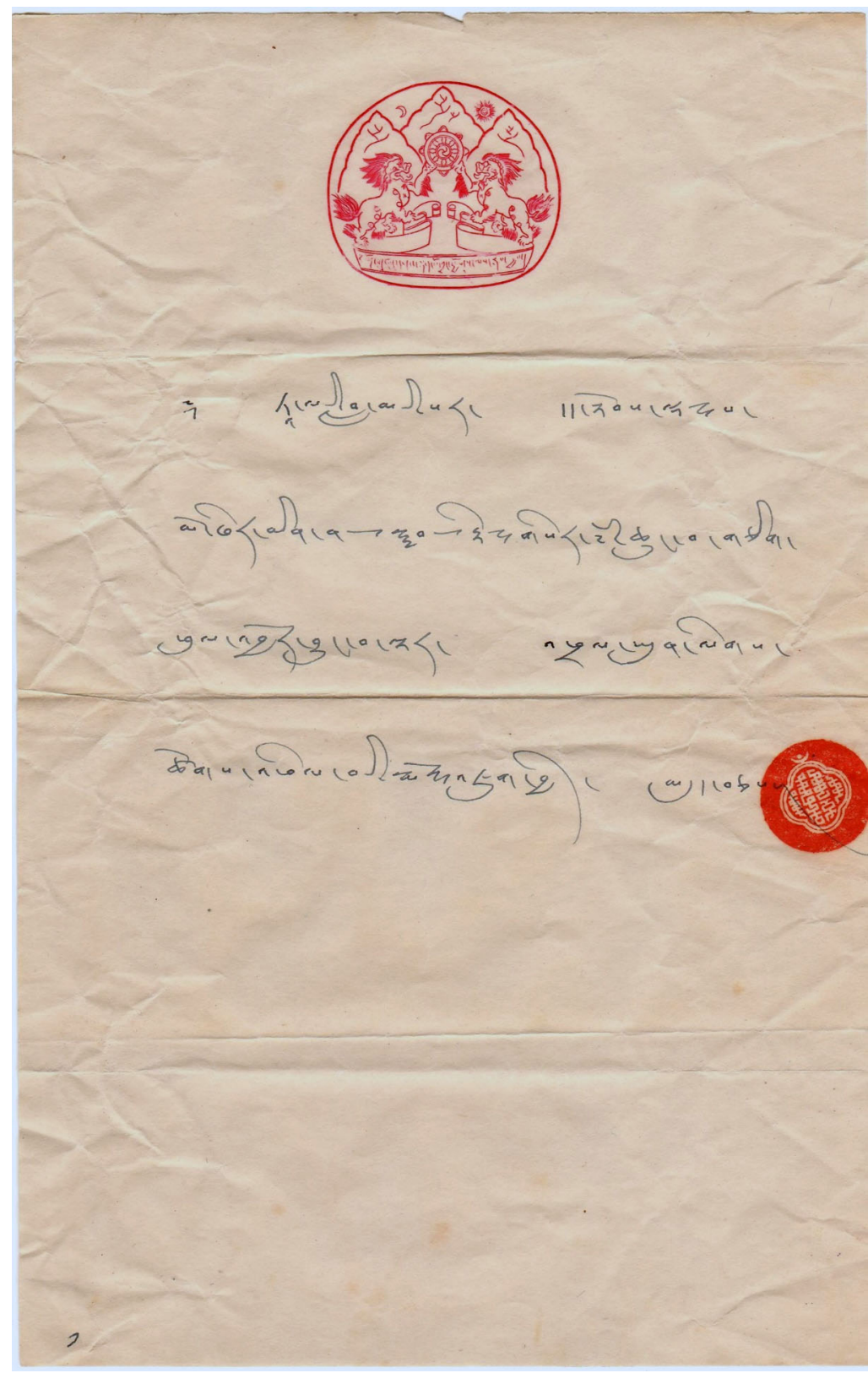

Фото 25. Письмо из Центральной тибетской администрации [Photo 25. Letter from the Central Tibetan Administration] 


\section{Источниковедение}

Архив свидетельствует о связях французских калмыков Зольвановых с буддийскими священнослужителями, прежде всего с геше Вангъялом, и о знании религиозных традиций, а также о бережном отношении к историко-культурному наследию.

Религиозная составляющая для идентичности калмыков являлась значимой. Калмыки, оказавшиеся в эмиграции, уже в 1923 г. открыли в Белграде буддийский храм, а в 1929 г. освятили вновь построенный большой храм, вмещавший 150 человек [Миленкович 1998]. После эмиграции из стран Европы в США в калмыцкой общине, разделившейся по субэтническому признаку, были открыты несколько храмов. В европейских же странах в послевоенное время в калмыцкой диаспоре не осталось священнослужителей, белградский храм, разрушенный во время военных действий, не функционировал. Тем более важной являлась связь французских калмыков с буддийскими учителями.

Материалы переписки представляют несомненный интерес, они свидетельствуют о широких связях калмыцкой диаспоры и об их религиозной традиции, о знании историко-культурного наследия. Наличие в коллекции семьи французских калмыков писем, в которых они не были ни адресатами, ни адресантами, позволяет предположить, что эти документы относятся к переписке геше Вангьяла, которая сохранилась в семье Зольвановых как память о визите геше Вангъяла, побывавшего в 1970 г. у французских калмыков, и священнослужитель, отправляясь в дальнейший путь, оставил полученную им корреспонденцию во Франции.

В условиях изоляции от остального буддийского мира французские калмыки, порой не имея оригинальных предметов буддийского культа, довольствовались копиями изображений. Особо ценными являлись репродукции. Каждый предмет имел большую ценность как предмет поклонения.

Семейная коллекция французских калмыков ценна тем, что она свидетельствует о глубокой сохранности буддийской традиции в эмиграции, дает представление о сакральных предметах поклонения, об исторических ценностях калмыков, а также о связях калмыков зарубежья не только с другими диаспорами, но также и с буддийскими монахами - калмыками, тибетцами. Коллекция, поступившая в научный архив, имеет важное культурно-историческое значение.

\section{Литература}

Бакаева 2019 - Бакаева Э. П. Расширяющееся культурное пространство: пример калмыцкой диаспоры (буддизм и идентичность, миграции и современные технологии) [электронный ресурс] // Новые исследования Тувы. 2019. № 3. С. 116-134. URL: https://nit.tuva.asia/nit/article/view/869/1262 (дата обращения: 01.02.2020). DOI: $10.25178 /$ nit.2019.3.10

Борманжинов 1997 - Борманжинов А. Ламы калмыцкого народа: Ламы донских калмыков. Элиста: КИГПИ, 1997. 72 с.

В Центральном хуруле 2018 - В Центральном хуруле Калмыкии прошла презентация документального фильма о геше Нгаванге Вангьяле [электронный ресурс] // Инф. портал Республики Калмыкия Uralan.Info. 15.02.2018. URL: http://uralan. info/index.php/nashi-traditsii/item/7077-v-tsentralnom-khurule-kalmykii-proshla- 
prezentatsiya-dokumentalnogo-filma-o-geshe-ngavange-vangyale (дата обращения: 01.02.2021)

Геше Вангъял 1993 - Геше Вангъял. Лестница, украшенная драгоценностями / пер. с англ. Н. Овшиевой. Элиста: Либон, 1993. 192 с.

Дилова-хутухта 2018 - Дилова-хутухта Монголии. Политические мемуары и автобиография перевоплощения буддийского ламы / пер. с англ. Е. В. Гордиенко, отв. ред. рус. изд. С. Л. Кузьмин и Ж. Оюунчимэг, лит. ред. Н. Г. Иноземцева. М.: Сохраним Тибет, 2018. $352 \mathrm{c}$.

Манджиев 2016 - Манджсиев C. Ламы - на фото 1943 года [электронный ресурс] // Хальмг унн. 23.06.2016. URL: http://halmgynn.ru/3768-lamy-na-foto-1943-goda.html (дата обращения: 01.02.2021).

Миленкович 1998 - Миленкович Т. Калмици у Србији. 1920-1944. Београд: Тraco, $1998.246 \mathrm{c}$.

Хопкинс 2009 - Хопкинс Дж. Калмыцкий вклад в развитие буддизма на Западе // Буддизм в России. 2009. № 42. С. 25-27.

Bormanshinov 1991 - Bormanshinov A. The Lamas of the Don Kalmyk People: the Don Kalmyk Lamas. Bloomington: Indiana University, 1991. 63 p.

Tibetan Buddhist Learning Center — Tibetan Buddhist Learning Center, [электронный pecypc] // http://labsum.com/ (дата обращения: 01.02.2021).

Urubshurow 2013 - Urubshurow D. From Russia with Love. The untold story of how Tibetan Buddhism first came to America [электронный ресурс] // Incredible Geshe Wangyal. Blog of Tsem Rinpoche. Dec. 8, 2013. URL: https://www.tsemrinpoche.com/ tsem-tulku-rinpoche/buddhas-dharma/from-russia-with-love.html (дата обращения: 01.02.2021).

Rubel 1967 - Rubel P. G. The Kalmyk Mongols: a study in continuity and change (Indiana University Publications. Uralic and Altaic Series. Vol. 64). Bloomington: Indiana University; The Hague: Mouton and Co. XIV, 1967. 282 p.

\section{References}

Bakaeva E. P. The expanding cultural space: a case study of the Kalmyk diaspora (Buddhism and identity, migrations and modern technologies). The New Research of Tuva. 2019. No. 3. Pp. 116-134. Available at: https://nit.tuva.asia/nit/article/view/869/1262 (accessed: February 1, 2020). (In Russ.) DOI: 10.25178/nit.2019.3.10

Bormanshinov A. The Lamas of the Kalmyk People: The Don Kalmyk Lamas. Elista: Humanities and Applied Research Institute of Kalmykia, 1997. 72 p. (In Russ.)

Bormanshinov A. The Lamas of the Kalmyk People: The Don Kalmyk Lamas. Bloomington: Indiana University, 1991. 63 p. (In Eng.)

Central Khurul of Kalmykia hosts premier screening about Ven. Ngawang Wangyal. On: Uralan.Info News Portal. Posted on February 15, 2018. Available at: http://uralan. info/index.php/nashi-traditsii/item/7077-v-tsentralnom-khurule-kalmykii-proshlaprezentatsiya-dokumentalnogo-filma-o-geshe-ngavange-vangyale (accessed: February 1, 2021). (In Russ.)

Dilowa Khutukhtu. Dilowa Khutukhtu of Mongolia: Political Memoirs and Autobiography of the Reincarnate Buddhist Lama. E. Gordienko (transl.), S. Kuzmin and Zh. Oyuunchimeg (sc. eds.), N. Inozemtsev (lit. ed.). Moscow: Save Tibet Foundation, 2018. 352 p. (In Russ.)

Hopkins J. Development of Buddhism in the West: the Kalmyk impact. Buddizm v Rossii. 2009. No. 42. Pp. 25-27. (In Russ.)

Mandzhiev S. Lamas - on photos dating to 1943. Khal'mg unn. 2016, June 23. Available at: http://halmgynn.ru/3768-lamy-na-foto-1943-goda.html (accessed: February 1, 2021). (In Russ.)

Milenkovich T. Kalmyks in Serbia, 1920-1944. Belgrade: Traco, 1998. 246 p. (In Serb.) 


\section{Источниковедение}

Rubel P. G. The Kalmyk Mongols: A Study in Continuity and Change (Indiana University Publications. Uralic and Altaic Series. Vol. 64). Bloomington: Indiana University; The Hague: Mouton and Co. XIV, 1967. 282 p. (In Eng.)

Tibetan Buddhist Learning Center. Available at: http://labsum.com/ (accessed: February 1, 2021). (In Eng.)

Urubshurow D. From Russia with love. The untold story of how Tibetan Buddhism first came to America. Incredible Geshe Wangyal. On: Blog of Tsem Rinpoche. Posted on December 8, 2013. Available at: https://www.tsemrinpoche.com/tsem-tulku-rinpoche/ buddhas-dharma/from-russia-with-love.html (accessed: February 1, 2021). (In Eng.)

Wangyal, Geshe. The Jewelled Staircase. N. Ovshieva (transl.). Elista: Libon, 1993. 192 p. (In Russ.) 